\title{
Extreme Bounds of Democracy
}

\author{
Martin Gassebner*, Michael J. Lamla ${ }^{\dagger}$ and James Raymond Vreeland ${ }^{\ddagger}$
}

October 15, 2008

\begin{abstract}
There are many stories of democracy but little consensus over which variables robustly determine its emergence and survival. We apply extreme bounds analysis to test the robustness of 59 factors proposed in the literature, evaluating over 1.7 million regressions of the emergence of democracy, and over 1.4 million regressions for the survival of democracy. The most robust determinants of the transition to democracy are the number of past transitions (a positive effect), whether the country is a member of the OECD (a positive effect), and GDP growth (a negative effect). There is also some evidence that fuel exporters and Muslim countries are less likely to see democracy emerge, although the latter finding is driven entirely by oil producing Muslim countries. Regarding the survival of democracy, the most robust determinants are level of economic development (a positive effect) and, interestingly, the number of past transitions (a negative effect) - indicating that both supporters and subverters of democracy learn from history. There is also some evidence that having a former military leader as the chief executive has a negative effect on democratic survival, while having other democracies as neighbors has a reinforcing effect.
\end{abstract}

\footnotetext{
${ }^{*}$ ETH Zurich, KOF Swiss Economic Institute, gassebner@kof .ethz.ch

${ }^{\dagger}$ ETH Zurich, KOF Swiss Economic Institute, lamla@kof .ethz.ch

$\doteqdot$ †ale University, james.vreeland@yale.edu
} 


\section{Introduction}

There are many stories of democracy. Efforts to test the empirical implications of various theories of why democracy emerges or breaks down have produced a long list of variables that purportedly explain these transitions. There is, however, little consensus over which variables robustly determine democracy. We address this issue by applying extreme bounds analysis (EBA) as suggested by Leamer (1983) and Levine and Renelt (1992) and modified by Sala-i-Martin (1997) to test the robustness of 59 proposed factors. We assess both the factors leading to the emergence of democracy as well as the factors explaining the persistence of democracy. To be clear from the outset, our approach is extreme. We evaluate over 1.7 million regressions of the emergence of democracy, and over 1.4 million regressions for the survival of democracy.

The most striking of our findings is that most of the variables suggested in the literature do not survive EBA. While many of these factors are shown elsewhere to have significant effects in plausible and well-specified models, when put to the rigors of being tested alongside many other plausible variables, the significance simply does not survive.

We do not suggest that this implies these factors are unimportant. Many of the findings that fail our EBA test are valid within the confines of the original statistical model proposed in the literature. Our empirical approach focuses on reduced form models. Moreover, to the extent that some variables fail our test, this could be because they are poor proxies for otherwise strong theories of democracy. The standard of surviving the test of EBA is just a very a high one, and only the strongest of relationships survive it.

And some variables do indeed survive. We suggest that these variables may be the most important factors determining democracy. Regarding transitions to democracy, we find that economic growth has a robust negative effect. This finding, standing in stark contrast to modernization theory, suggests that autocracies with strong economic performance 
are unlikely to see democracy emerge. Instead, economic contraction causes dictatorships to break down. Also in contrast to modernization theory, but consistent with the argument of Przeworski et al. (2000), the level of GDP per capita does not have a robust relationship with the emergence of democracy. Following the literature on the diffusion of democracy (e.g., Pevehouse 2002a,b), we find evidence that membership in one specific international organization has a positive effect on transitions to democracy: the Organisation for Economic Co-operation and Development (OECD). Previous regime transitions also increase the likelihood of the emergence of democracy. The only other variables for which we find any evidence of a robustly significant effect are fuel exports (confirming Ross 2001 and Jensen and Wantchekon 2004) and the share of the population that is Muslim (as cultural theorists argue). Both lose some statistical significance when included exclusively with the other highly robust variables, however, and we suspect that they are really fixed effects of the Middle East. Tests certainly show that the effect of Islam is driven by fuel exports as the effect does not exist among non-fuel exporting Muslim countries.

Regarding the survival of democracy, the most robust determinants are level of economic development (a positive effect) and, interestingly, the number of past transitions (a negative effect) - indicating that both supporters and subverters of democracy learn from history. These findings confirm Przeworski et al. (2000) and Przeworski (2005). There is also some evidence that having a former military leader as the chief executive has a negative effect on democratic survival (in line with Cheibub 2006), while having other democracies as neighbors has a reinforcing effect (consistent with Gleditsch 2002). These latter findings, however, lose significance in the presence of the number of past transitions.

We conclude that while there are many plausible theories of democracy, there are few robust predictors that we can trust as reliable. For policymakers interested in promoting democracy based on such reliable predictors, we suggest that there is little difference policy can make when it comes to the emergence of democracy. But promoting investment in 
dictatorships - encouraging vigorous economic growth - is certainly not likely to cause a dictatorial regime to fall. ${ }^{1}$ Yet, when it comes to promoting the survival of nascent democracies, raising the level of development helps. So it seems that if the leader of a wealthy democracy decided to make the promotion of democracy a foreign policy goal, and he was willing to spend, say, $\$ 500$ billion, the money would be better spent helping poor, established democracies develop economically rather than devoted to a country where democracy had never previously existed.

The paper proceeds as follows. We begin with a brief review of the literature. We then introduce the EBA method in detail and subsequently present the results. We conclude by summarizing our findings and deriving policy conclusions.

\section{Background}

The earliest large-n studies of democracy are culturalist. Almond and Verba (1963), for example, use survey-based research in five countries to show that a "participant" culture (as opposed to a "subject" or "parochial" culture) is required for democracy. This "civic culture" argument is tested cross-nationally in the work of Inglehart (1988), who finds that democracy is correlated with the percentage of people reporting high levels of interpersonal trust, low levels of support for revolutionary change, and high levels of life satisfaction.

These culturalist findings are disputed by Seligson (2003), who shows that the cultural connections to democracy disappear when one controls for level of economic development. Przeworski et al. (2000) test a full range of other cultural variables, finding that none has a robust relationship with democracy once one accounts for level of economic development.

Economic explanations of democracy date back to Lipset (1959) who is often cited as the first "modernization theorist." Modernization theory argues that as countries develop

\footnotetext{
${ }^{1}$ See Rosendorff (2001) for a formal presentation as to why. Also see Boix (2003) and Acemoglu and Robinson (2006).
} 
economically, social structures become too complex for authoritarian regimes to manage - technological change endows owners of capital with some autonomy and private information, complex labor processes require active cooperation rather than coercion, and civil society emerges. ${ }^{2}$ At some point in this process, dictatorship collapses and democracy emerges as the alternative.

Critical of modernization theory, Huntington (1968) adds that sustainable democracy requires political development along with economic development. While he basically agrees that economic development is a prerequisite for democracy, without political development, rapid economic development can also destabilize democracies.

In their expansive large-n study of democracy and development, Przeworski et al. (2000) thoroughly explore the relationship. They begin with the observation that the correlation between level of economic development and democracy is strong. They question, however, the process by which this correlation is driven. They suggest, in contrast to modernization theorists, that this correlation is possible even if the emergence of democracy is completely random with respect to economic development. The correlation may be driven instead by a relationship between economic development and the survival of democracy.

This is in fact what their book argues. The emergence of democracy has no relationship with level of economic development; the correlation instead is entirely driven by the survival of democracy. In another work, Przeworski (2005, p.253) argues that "democracy prevails in developed societies because too much is at stake in turning against it." Conversely, in poor democracies, "the value of becoming a dictator is greater and the accumulated cost of destroying capital stock is lower" (Przeworski and Limongi, 1997, p.166 fn.1).

It should be noted, however, that while Przeworski et al. (2000) show that transitions to democracy are not well predicted by economic development and survival of democracy is, the estimated effect of economic development on the transition to democracy is statistically

\footnotetext{
${ }^{2}$ See Przeworski et al. (2000).
} 
significant in their specification. ${ }^{3}$ We suspect (and show below) that it is not a robust relationship.

One important drawback of the Przeworski et al. (2000) study is that it ignores the oil rich countries of the Middle East. As these scholars were originally interested in estimating the effect of regime on economic growth, they chose not to include oil rich countries, whose process of augmenting GDP per capita is much different from that of other countries. Nevertheless, these dictatorships - with their high levels of GDP per capita - present a real challenge to modernization theory that should be considered.

Some argue that political regime itself depends on the availability of oil and other natural resources. Ross (2001), as well as Jensen and Wantchekon (2004) argue that there is a resource curse whereby the rents from natural resources enable dictatorial regimes to use low taxes and high spending to maintain power.

Boix's (2003) compelling story provides a game theoretic mechanism to explain the effect of natural resources. ${ }^{4}$ He argues that level of economic development, income distribution, and - importantly - asset specificity together impact the probability of the emergence of democracy. Where asset specificity is high and the income distribution is highly skewed, such as in many oil-rich countries, the rich face severe redistributional consequences for allowing popular sovereignty, and they have no credible threat to flee the country taking their productive capacity with them. Thus, it is in their interest to pay high costs of repressing democracy, maintaining dictatorial rule. Note that if asset specificity is low, as in South Africa, for example, the rich have a credible exit threat. If the rich flee the country, taking the productive capacity along with them, they can severely harm the national economy. This credible threat restrains the redistributional demands of the poor and may make democracy possible even in countries with relatively low levels of

\footnotetext{
${ }^{3}$ The insignificant coefficient reported indicates that the difference between the coefficients for the emergence and survival of democracy is not significant.

${ }^{4}$ See also Boix and Stokes (2003) and Rosendorff (2001) on this matter.
} 
economic development, such as India. Asset specificity aside, if redistributional demands diminish at higher levels of economic development, Boix argues that economic development should make democracy more likely both to emerge and to survive.

Acemoglu and Robinson (2006) also propose a theory of democracy where elites may prefer dictatorship but must pay the costs of repression as the masses threaten disorder. Where repression costs are high and elites cannot credibly promise concessions otherwise, democracy can offer a compelling alternative under specific conditions. Factors identified by their theory of democracy include measures of civil society, political institutions, economic crises, income distribution, the structure of the economy, and the forces of globalization. $^{5}$

Another approach that has implications for the Middle East considers the effects of "diffusion." Consider the work of Gleditsch (2002), summarized nicely by the title of his book: All (International) Politics are Local. Diffusion theorists suggest that through various forces that spill over borders - political, cultural, and economic - the political regime of one country is likely to be correlated with regimes of neighboring countries. ${ }^{6}$ Thus we have solidly democratic regions, such as Europe, dictatorial regions, such as the Middle East, and regions where countries tend to transition together in waves, such as Latin America.

A related story is suggested by Pevehouse (2002a,b), who argues that participation in international organizations with many democratic members influences both the emergence and survival of democracy. He develops an innovative mechanism by which diffusion may operate - participation in regional organizations provides incentives for countries to encourage democratic standards amongst the membership.

This stylized and brief sketch of the literature on the determinants of democracy demon-

\footnotetext{
${ }^{5}$ For a challenge to the empirical findings of Acemoglu and Robinson (2006), see Freeman and Quinn (2008).

${ }^{6}$ Also see Simmons and Elkins (2004, 2005), Meseguer (2005), Gilardi (2005), and Way (2005).
} 
strates that there is a vigorous debate. In addition to the "culturalist," "modernization," "credible threat," and "diffusion" stories of democracy that we have briefly outlined, Ta-

ble 8 in the Appendix presents a summary of 14 published panel studies on the determinants of democracy. Most studies, however, present but a handful of potential specifications, controlling for very few of the possible combinations of different variables. Many of them simply ignore other theories when testing their own central arguments. Of course, each study presents valid theoretical justifications for how their particular specifications are chosen. But looking across the literature, there appears to be little consensus on the theory. The only factor that all seem to agree is important is level of economic development, and even here scholars disagree as to how it matters. As for the effects of other proposed factors, findings that are presented as statistically significant in the presence of some variables may not be significant in the presence of other variables proposed by different scholars. We, therefore, suggest testing the bounds of the significance of all previously considered variables.

\section{Empirical Method}

The purpose of EBA is to validate the statistical significance of the effect of a potential explanatory variable in the presence of different combinations of other control variables. We do not merely check the significance of a variable's coefficient from some specifications rather, we keep track of its coefficient in all possible specifications with additional control variables entering in groups of one, two, and three at a time (along with a core set of standard control variables over which there is a consensus in the literature, included in all regressions). In the end, we present summary statistics reporting the proportion of the coefficient's distribution that is greater than or less than 0 (whichever is larger), the proportion of times the coefficient is significant at the $5 \%$ level, the median coefficient, and 
its median standard error.

We apply the EBA on a basic model of democracy which assumes that the probability of observing democracy at time $t$ (measured in years in our data) follows a first order Markov process. Let $D$ be a dummy variable coded 1 if a country is a democracy, and 0 otherwise. Then,

$$
\operatorname{Pr}\left(D_{i, t} \mid D_{i, t-1}\right)=\left(1-D_{i, t-1}\right) \cdot \operatorname{Pr}\left(D_{i}, t \mid D_{i, t-1}=0\right)+\left(D_{i, t-1}\right) \cdot \operatorname{Pr}\left(D_{i}, t \mid D_{i, t-1}=1\right)
$$

As the likelihood function for this model is additively separable, it can be easily estimated as two logistic functions with the transition probabilities defined as follows:

$$
\begin{aligned}
& \operatorname{Pr}\left(D_{i, t} \mid D_{i, t-1}=0\right)=\Lambda\left(\beta^{A D^{\prime}} x_{i, t-1}\right) \\
& \operatorname{Pr}\left(D_{i, t} \mid D_{i, t-1}=1\right)=\Lambda\left(\beta^{D D^{\prime}} x_{i, t-1}\right)
\end{aligned}
$$

where $\Lambda$ is the cumulative distribution function of the logistic distribution, $x_{i, t-1}$ is the vector of (lagged) variables that determine democracy, $\beta^{A D}$ is a vector of coefficients capturing the effects of these variables on the probability of transition from Authoritarianism to $\boldsymbol{D}$ emocracy, and $\beta^{D D}$ is a vector of coefficients capturing the effects of these variables on the survival of democracy ("transitioning" from $\boldsymbol{D}$ emocracy to $\boldsymbol{D}$ emocracy). While it is of course not necessary to assume that the same variables determine both the emergence and survival of democracy, most scholars in practice do, and we will be testing all variables in both setups. 
To conduct an EBA, we define:

$$
\begin{aligned}
& \beta^{A D^{\prime}} x_{t-1}=\beta_{M}^{A D^{\prime}} M_{t-1}+\beta_{F}^{A D^{\prime}} F_{t-1}+\beta_{Z}^{A D^{\prime}} Z_{t-1} \\
& \beta^{D D^{\prime}} x_{t-1}=\beta_{M}^{D D^{\prime}} M_{t-1}+\beta_{F}^{D D^{\prime}} F_{t-1}+\beta_{Z}^{D D^{\prime}} Z_{t-1},
\end{aligned}
$$

where $M$ is a vector of "commonly accepted" explanatory variables; and $F$ is a vector containing the variable of interest; and $Z$ is a vector containing up to three possible additional explanatory variables which, according to the broader literature, are related to the dependent variable (as in Levine and Renelt, 1992).

Using this setup, we conduct a long series of regressions. The commonly accepted variables in $M$ are included as control variables in every regression. All other variables enter one at a time into $F$. The variable in $F$ is then tested while controlling for $M$ and, following Levine and Renelt (1992), (up to) three control variables at a time in $Z$. The variables included in the $Z$ vector change for each regression as all possible permutations of the remaining control variables are tested. The values of the coefficient $\beta_{F}$ along with the corresponding standard error and its cumulative distribution are recorded and averaged (the same is done for the coefficients of the variables in $M$ ). After this, a new control variable replaces the previous in $F$, and the procedure is repeated. The process continues until all variables have been tested in $F$.

According to the original EBA test as proposed by Leamer (1983), the effect of a variable is considered robust only if the lower extreme bound for $\beta_{F}$ - defined as the lowest value for $\beta_{F}$ minus two standard deviations - and the upper extreme bound for $\beta_{F}$ - defined as the highest value for $\beta_{F}$ plus two standard deviations - both have the same sign.

Sala-i-Martin (1997) argues that this testing criterion is far too strong for most variables. If the distribution of the parameter of interest has both positive and negative support, then a researcher will likely find at least one regression model for which the esti- 
mated coefficient changes sign if enough regressions are run. Consequently, we report the percentage of the regressions in which the coefficient of the variable $F$ is statistically different from zero at the five percent significance level. Furthermore, instead of only analyzing the extreme bounds of the estimates of the coefficient of a particular variable, we follow Sala-i-Martin's (1997) recommended procedure and analyze the entire distribution of $\beta_{F}$. Thus, we report $\mathrm{CDF}(0)$, the proportion of all of the cumulative distribution functions of the different estimates of $\beta_{F}$ lying on one side of zero. $\operatorname{CDF}(0)$ indicates the larger of the areas under the density function either above or below zero (whether this happens to be $\operatorname{CDF}(0)$ or $1-\operatorname{CDF}(0))$. So $\operatorname{CDF}(0)$ is always between 0.5 and 1.0. We report the median parameter estimate of $\beta_{F}$ and the corresponding median standard error. ${ }^{7}$

One important question as to how to proceed with EBA is what variables belong in the vector $M$ of "commonly accepted" variables, included in every regression. In our view, GDP per capita (measured in purchasing power parities) is the only non-contentious regressor. Beyond this variable, none other is included in all other studies. Thus, we choose not to prejudge the importance of other explanatory variables for the outcome of the EBA. We put all other variables through the $F$ vector and test their relevance individually. The list of all variables, their definitions, and sources is given in Table $1 .{ }^{8}$ In order to somewhat

\footnotetext{
${ }^{7}$ In contrast to Sala-i-Martin, who suggests weighting results according to the goodness-of-fit of each regression, we use the unweighted median parameter estimate of $\beta_{F}$, median standard error, and $\operatorname{CDF}(0)$. This is because missing data pose a problem. The number of observations changes depending on which variables are included in each regression. Thus, the dataset essentially changes. In this context, Sturm and de Haan (2002) show that the goodness-of-fit measure may not be a good indicator of the probability that a model is the true model and that the weights constructed in this way are not invariant to linear transformations of the dependent variable. Note that sometimes the algorithm breaks down and reports back extraordinarly high coefficients, so we refrain from using the average parameter estimate and its corresponding average standard error, instead reporting their respective medians to increase the robustness of our results.

${ }^{8}$ As we deal with so many variables multicollinearity could potentially be a problem. We thus checked the correlations between all our explanatory variables. There are only 11 (out of 1,541) pairwise correlations above 0.8. Some of them are very obvious candidates. All are reported as follows: oil producing countries and OPEC; Spanish colony and Spanish language; GDP per capita and life expectancy; GDP per capita and telephone mainlines; GDP per capita and globalization; infant mortality and employment in agriculture; GPD per capita growth and GDP growth; television sets and telephone mainlines; globalization and telephone mainlines; globalization and television sets; European settlers 1900 and population share 16-51.
} 
mitigate potential endogeneity problems and so we can interpret the relationships as being (Granger-)causal, we followed the literature and lagged nearly all variables one year. The exception is the contagion variable; following the proponents of this variable, Pevehouse (2002a,b) and Gleditsch (2002), we do not lag the share of neighboring countries that are democracies. This allows the variable to have a contemporaneous effect. 9 Obviously for time-invariant variables, lagging is not an issue.

As it is pervasive in the literature we use pooled logit regressions. We include all timeinvariant variables previously proposed in the literature to proxy for fixed country effects. Including fixed country effects directly (via conditional fixed effects logit estimations), reduces the sample size to only 200 observations which makes inference unreliable and meaningless (which is indeed why no study in the literature we are aware of uses the fixed effects approach).

So, to summarize, the basic idea of the EBA is to run many regressions continuously permutating through combinations of explanatory variables, testing how the variable in the center of attention "behaves." Each regression estimation equation includes GDP per capita as well as a combination of up to three further control variables. This tests the significance of GDP per capita. In the $F$ vector regressions, GDP per capita is included as well the variable in focus plus up to three additional variables out of the $Z$ vector. Overall, we estimate a total of 1,776,379 specifications for the emergence of democracy and 1,492,029 specifications for the survival of democracy. ${ }^{10}$

As a measure of democracy, we use the Przeworski et al. (2000) dichotomous variable (which follows Schumpeter's (1942) conception of regime): democracy is the political system in which key government offices are filled through contested elections. The definition

Otherwise, the pairwise correlations were quite low.

${ }^{9}$ Analysis of our final results shows that results are actually stronger when we do lag the variable. Results are available on request.

${ }^{10}$ The number of regressions differ because some estimations break down due to a the lack of observations. $3 \%$ of all possible combinations break down for the emergence of democracy while $18 \%$ were problematic for the survival of democracy. 
has two parts: "key government office," which they define as the executive and the legislature; and "contested," which implies that more than one party has some probability of winning office through election. ${ }^{11}$ Elections must be associated with some ex ante uncertainty, and be subject to ex post irreversibility. Put succinctly, "democracy is a system in which incumbents lose elections and leave office when the rules so dictate" (Przeworski et al., 2000, p.54; also see Cheibub et al. 2008).

Table 1: Variables - definitions, sources and previous studies

\begin{tabular}{|c|c|c|c|}
\hline Variable & Definition & Source & Proposed by \\
\hline$\overline{\text { Africa }}$ & $\begin{array}{l}\text { Dummy variable for African } \\
\text { Countries }\end{array}$ & $\begin{array}{l}\text { Easterly and } \\
\text { Sewadeh (2001) }\end{array}$ & $\begin{array}{lr}\text { Li and } & \text { Reuveny } \\
(2003) ; & \text { López- } \\
\text { Córdova and Meiss- } \\
\text { ner (2008) }\end{array}$ \\
\hline Arable land & Arable land (hectares) & $\begin{array}{l}\text { World } \\
(2006)\end{array}$ & Crenshaw (1995) \\
\hline $\begin{array}{l}\text { Bonds invest- } \\
\text { ment }\end{array}$ & $\begin{array}{l}\text { Portfolio investment, bonds } \\
\text { (PPG + PNG) (NFL, current } \\
\text { US\$) }\end{array}$ & $\begin{array}{l}\text { World } \\
(2006)\end{array}$ & $\begin{array}{l}\mathrm{Li} \text { and } \\
(2003)\end{array}$ \\
\hline Colony & $\begin{array}{l}\text { Dummy variable if ever in a } \\
\text { colonial relationship }\end{array}$ & CEPII (2006) & $\begin{array}{l}\text { Barro (1999); Boix } \\
\text { and Stokes (2003) }\end{array}$ \\
\hline $\begin{array}{l}\text { Employment } \\
\text { in Agriculture }\end{array}$ & $\begin{array}{l}\text { Employment in Agriculture (\% } \\
\text { of total employment) }\end{array}$ & $\begin{array}{l}\text { World } \\
(2006)\end{array}$ & $\begin{array}{l}\text { Clague et al. (2001); } \\
\text { Crenshaw (1995) }\end{array}$ \\
\hline $\begin{array}{l}\text { Equity invest- } \\
\text { ment }\end{array}$ & $\begin{array}{l}\text { Portfolio investment, equity } \\
\text { (DRS, current US\$) }\end{array}$ & $\begin{array}{l}\text { World } \\
(2006)\end{array}$ & $\begin{array}{l}\text { Li and Reuveny } \\
(2003)\end{array}$ \\
\hline $\begin{array}{l}\text { English speak- } \\
\text { ing }\end{array}$ & $\begin{array}{l}1 \text { if English first language of at } \\
\text { least } 9 \% \text { of the population }\end{array}$ & CEPII (2006) & Clague et al. (2001) \\
\hline $\begin{array}{l}\text { European set- } \\
\text { tlers } 1900\end{array}$ & $\begin{array}{l}\text { Share of European settlers in } \\
\text { the country in } 1900\end{array}$ & $\begin{array}{l}\text { Acemoglu } \\
\text { and Robinson } \\
(2006)\end{array}$ & $\begin{array}{l}\text { Acemoglu and } \\
\text { Robinson (2006) }\end{array}$ \\
\hline $\begin{array}{l}\text { FDI net in- } \\
\text { flows }\end{array}$ & $\begin{array}{l}\text { Foreign direct investment, net } \\
\text { inflows ( } \% \text { of GDP) }\end{array}$ & $\begin{array}{l}\text { World Bank } \\
(2006)\end{array}$ & $\begin{array}{l}\text { Li and Reuveny } \\
(2003)\end{array}$ \\
\hline French colony & $\begin{array}{l}1 \text { if ever in colonial relationship } \\
\text { with France }\end{array}$ & CEPII (2006) & Barro (1999) \\
\hline $\begin{array}{l}\text { French speak- } \\
\text { ing }\end{array}$ & $\begin{array}{l}1 \text { if French first language of at } \\
\text { least } 9 \% \text { of the population }\end{array}$ & CEPII (2006) & Clague et al. (2001) \\
\hline
\end{tabular}

\footnotetext{
${ }^{11}$ Sometimes this is obvious, such as when incumbents lose elections and relinquish power (Przeworski 1991). Sometimes it is not, such as when incumbents successively win contested elections. Also see Vreeland (2003).
} 


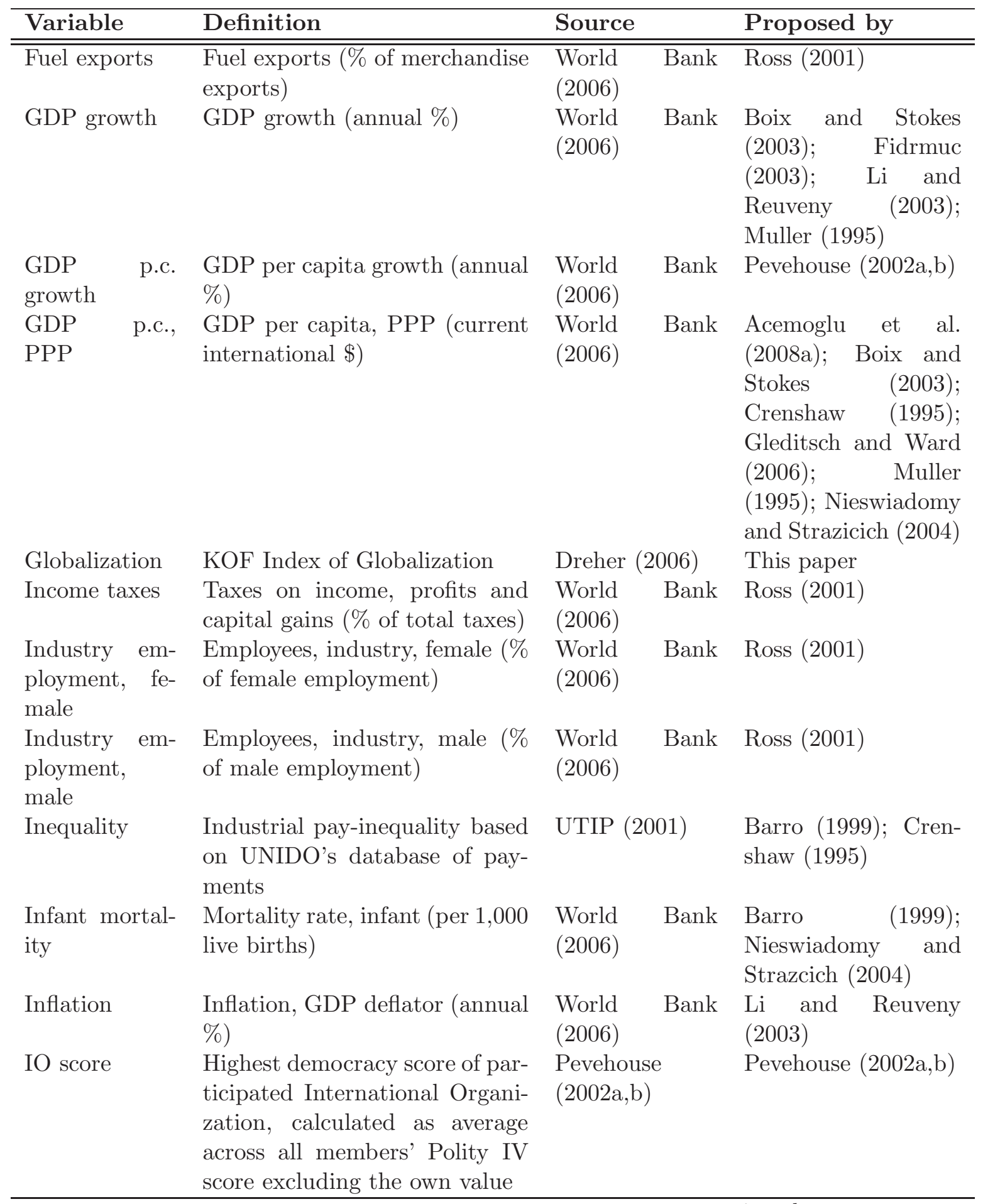

continued on next page... 


\begin{tabular}{|c|c|c|c|}
\hline Variable & Definition & Source & Proposed by \\
\hline $\begin{array}{ll}\text { IO } & \text { score, } \\
\text { change }\end{array}$ & $\begin{array}{l}\text { First difference of IO score (see } \\
\text { above) }\end{array}$ & $\begin{array}{l}\text { Pevehouse } \\
(2002 \mathrm{a}, \mathrm{b})\end{array}$ & "Pevehouse (2002a,b) \\
\hline Land area & Land area (hectares) & $\begin{array}{l}\text { World } \\
(2006)\end{array}$ & $\begin{array}{l}\text { López-Córdova and } \\
\text { Meissner (2008) }\end{array}$ \\
\hline Latin America & $\begin{array}{l}\text { Dummy variable for Latin } \\
\text { American countries }\end{array}$ & $\begin{array}{l}\text { Easterly and } \\
\text { Sewadeh (2001) }\end{array}$ & $\begin{array}{l}\text { López-Córdova and } \\
\text { Meissner (2008) }\end{array}$ \\
\hline $\begin{array}{l}\text { Life ex- } \\
\text { pectancy }\end{array}$ & $\begin{array}{l}\text { Life expectancy at birth, total } \\
\text { (years) }\end{array}$ & $\begin{array}{l}\text { World } \\
(2006)\end{array}$ & $\begin{array}{lr}\text { Barro (1999); } & \text { Clague } \\
\text { et al. } & \text { (2001); } \\
\text { Nieswiadomy } & \text { and } \\
\text { Strazcich } & \text { (2004); } \\
\text { Ross (2001) } & \end{array}$ \\
\hline Literacy & $\begin{array}{l}\text { Literacy rate, adult total (ages } \\
15 \text { and above) }\end{array}$ & $\begin{array}{l}\text { World } \\
(2006)\end{array}$ & Clague et al. (2001) \\
\hline Metal exports & $\begin{array}{l}\text { Ores and metals exports ( } \% \text { of } \\
\text { merchandise exports) }\end{array}$ & $\begin{array}{l}\text { World } \\
(2006)\end{array}$ & $\begin{array}{ll}\text { Crenshaw } & \text { (1995); } \\
\text { Ross (2001) }\end{array}$ \\
\hline Middle East & $\begin{array}{l}\text { Dummy for Countries from the } \\
\text { Middle East }\end{array}$ & $\begin{array}{l}\text { Easterly and } \\
\text { Sewadeh (2001) }\end{array}$ & $\begin{array}{l}\mathrm{Li} \text { and Reuveny } \\
(2003)\end{array}$ \\
\hline $\begin{array}{l}\text { Military ex- } \\
\text { penditure }\end{array}$ & $\begin{array}{l}\text { Military expenditure }(\% \text { of } \\
\text { GDP })\end{array}$ & $\begin{array}{l}\text { World Bank } \\
(2006)\end{array}$ & Ross (2001) \\
\hline $\begin{array}{l}\text { Military } \\
\text { leader }\end{array}$ & $\begin{array}{l}\text { Executive leader is a former } \\
\text { military officer }\end{array}$ & $\begin{array}{l}\text { Gandhi and } \\
\text { Przeworski } \\
(2006)\end{array}$ & Cheibub (2006) \\
\hline $\begin{array}{l}\text { Military per- } \\
\text { sonnel }\end{array}$ & Military personnel, total & $\begin{array}{l}\text { World Bank } \\
(2006)\end{array}$ & $\begin{array}{ll}\text { Crenshaw } & \text { (1995); } \\
\text { Ross (2001) }\end{array}$ \\
\hline Muslim share & Share of Muslim population & $\begin{array}{l}\text { Przeworski et } \\
\text { al. }(2000)\end{array}$ & $\begin{array}{l}\text { Barro (1999); Boix } \\
\text { and Stokes (2003); } \\
\text { Clague et al. (2001); } \\
\text { Muller (1995); Ross } \\
(2001)\end{array}$ \\
\hline $\begin{array}{l}\text { Neighboring } \\
\text { democracies }\end{array}$ & $\begin{array}{l}\text { Share of surrounding democra- } \\
\text { cies }\end{array}$ & $\begin{array}{l}\text { Own calcula- } \\
\text { tions }\end{array}$ & $\begin{array}{ll}\text { Gleditsch } & \text { and Ward } \\
(2006) ; & \text { Pevehouse } \\
(2002 \mathrm{a}) & \end{array}$ \\
\hline $\begin{array}{l}\text { Number of } \\
\text { past transi- } \\
\text { tions }\end{array}$ & $\begin{array}{l}\text { Number of previous transitions } \\
\text { between autocracy/democracy }\end{array}$ & $\begin{array}{l}\text { Przeworski et } \\
\text { al. }(2000)\end{array}$ & $\begin{array}{l}\text { Boix and Stokes } \\
(2003)\end{array}$ \\
\hline $\begin{array}{l}\text { OECD mem- } \\
\text { ber }\end{array}$ & $\begin{array}{l}\text { Dummy variable for OECD } \\
\text { membership }\end{array}$ & OECD (2008) & Ross (2001) \\
\hline Oil exporter & $\begin{array}{l}\text { Dummy variable for exporters } \\
\text { of fuel/oil }\end{array}$ & $\begin{array}{l}\text { Easterly and } \\
\text { Sewadeh (2001) }\end{array}$ & $\begin{array}{l}\text { Barro (1999); López- } \\
\text { Córdova and Meiss- } \\
\text { ner }(2008)\end{array}$ \\
\hline
\end{tabular}




\begin{tabular}{|c|c|c|c|c|}
\hline Variable & Definition & \multirow{2}{*}{\multicolumn{2}{|c|}{$\begin{array}{l}\text { Source } \\
\text { OPEC (2008) }\end{array}$}} & \multirow{2}{*}{$\begin{array}{l}\text { Proposed by } \\
\text { Nieswiadomy and } \\
\text { Strazcich }(2004)\end{array}$} \\
\hline $\begin{array}{ll}\begin{array}{l}\text { OPEC } \\
\text { ber }\end{array} & \end{array}$ & $\begin{array}{l}\text { Dummy variable for } \text { OPEC } \\
\text { membership }\end{array}$ & & & \\
\hline Openness & Trade ( $\%$ of GDP) & $\begin{array}{l}\text { World } \\
(2006)\end{array}$ & Bank & $\begin{array}{l}\mathrm{Li} \text { and Reuveny } \\
(2003) ; \text { López- } \\
\text { Córdova and Meiss- } \\
\text { ner (2008) }\end{array}$ \\
\hline $\begin{array}{l}\text { Population } \\
(\log )\end{array}$ & log of total population & $\begin{array}{l}\text { World } \\
(2006)\end{array}$ & Bank & $\begin{array}{lr}\text { Acemoglu et al. } \\
(2008 a) ; & \text { Barro } \\
(1999) ; & \text { López- } \\
\text { Córdova } & \text { and } \\
\text { Meissner } & \text { (2008); } \\
\text { Nieswiadomy } & \text { and } \\
\text { Strazcich (2004) }\end{array}$ \\
\hline $\begin{array}{l}\text { Population } \\
\text { share } 0-14\end{array}$ & $\begin{array}{l}\text { Population ages } 0-14 \text { (\% of to- } \\
\text { tal) }\end{array}$ & $\begin{array}{l}\text { World } \\
(2006)\end{array}$ & Bank & $\begin{array}{l}\text { Acemoglu et al. } \\
(2008 \mathrm{a})\end{array}$ \\
\hline $\begin{array}{l}\text { Population } \\
\text { share } 15-64\end{array}$ & $\begin{array}{l}\text { Population ages } 15-64 \text { ( } \% \text { of to- } \\
\text { tal) }\end{array}$ & $\begin{array}{l}\text { World } \\
(2006)\end{array}$ & Bank & $\begin{array}{l}\text { Acemoglu et al. } \\
\text { (2008a) }\end{array}$ \\
\hline $\begin{array}{l}\text { Population } \\
\text { share } 65+\end{array}$ & $\begin{array}{l}\text { Population ages } 65 \text { and above } \\
\text { (\% of total) }\end{array}$ & $\begin{array}{l}\text { World } \\
(2006)\end{array}$ & Bank & $\begin{array}{l}\text { Acemoglu et al. } \\
(2008 \mathrm{a})\end{array}$ \\
\hline $\begin{array}{l}\text { Portfolio } \\
\text { investment }\end{array}$ & $\begin{array}{l}\text { Portfolio investment, excluding } \\
\text { LCFAR (BoP, current US\$) }\end{array}$ & $\begin{array}{l}\text { World } \\
(2006)\end{array}$ & Bank & $\begin{array}{l}\mathrm{Li} \text { and Reuveny } \\
(2003)\end{array}$ \\
\hline $\begin{array}{l}\text { Portuguese } \\
\text { colony }\end{array}$ & $\begin{array}{l}1 \text { if ever in colonial relationship } \\
\text { with Portugal }\end{array}$ & CEPII & $006)$ & Barro (1999) \\
\hline $\begin{array}{l}\text { Portuguese } \\
\text { speaking }\end{array}$ & $\begin{array}{l}1 \text { if Portuguese first language of } \\
\text { at least } 9 \% \text { of the population }\end{array}$ & CEPII & $006)$ & Clague et al. (2001) \\
\hline $\begin{array}{l}\text { Service em- } \\
\text { ployment, } \\
\text { female }\end{array}$ & $\begin{array}{l}\text { Employees, services, female (\% } \\
\text { of female employment) }\end{array}$ & $\begin{array}{l}\text { World } \\
(2006)\end{array}$ & Bank & Ross (2001) \\
\hline $\begin{array}{l}\text { Service em- } \\
\text { ployment, } \\
\text { male }\end{array}$ & $\begin{array}{l}\text { Employees, services, male ( } \% \text { of } \\
\text { male employment) }\end{array}$ & $\begin{array}{l}\text { World } \\
(2006)\end{array}$ & Bank & Ross (2001) \\
\hline $\begin{array}{l}\text { Settler mortal- } \\
\text { ity }(\log )\end{array}$ & $\begin{array}{l}\log \text { of historical mortality rates } \\
\text { of potential European settlers }\end{array}$ & $\begin{array}{l}\text { Acemo } \\
\text { and I } \\
(2006)\end{array}$ & jinson & $\begin{array}{l}\text { Acemoglu and } \\
\text { Robinson (2006) }\end{array}$ \\
\hline Socialist & $\begin{array}{l}1 \text { if present or former socialist } \\
\text { country }\end{array}$ & $\begin{array}{l}\text { Easterl } \\
\text { Sewade }\end{array}$ & $\begin{array}{r}\text { and } \\
(2001)\end{array}$ & Muller (1995) \\
\hline $\begin{array}{l}\text { Spanish } \\
\text { colony }\end{array}$ & $\begin{array}{l}1 \text { if ever in colonial relationship } \\
\text { with Spain }\end{array}$ & CEPII & 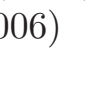 & Barro (1999) \\
\hline $\begin{array}{l}\text { Spanish } \\
\text { speaking }\end{array}$ & $\begin{array}{l}1 \text { if Spanish first language of at } \\
\text { least } 9 \% \text { of the population }\end{array}$ & CEPII & $006)$ & Clague et al. (2001) \\
\hline
\end{tabular}

continued on next page... 


\begin{tabular}{|c|c|c|c|c|}
\hline Variable & Definition & Source & & Proposed by \\
\hline Tax revenue & Tax revenue (\% of GDP) & $\begin{array}{l}\text { World } \\
(2006)\end{array}$ & $\overline{\overline{B a n k}}$ & $\overline{\text { Ross (2001) }}$ \\
\hline $\begin{array}{l}\text { Telephone } \\
\text { mainlines }\end{array}$ & $\begin{array}{l}\text { Telephone mainlines (per } 1,000 \\
\text { people) }\end{array}$ & $\begin{array}{l}\text { World } \\
(2006)\end{array}$ & Bank & Ross (2001) \\
\hline TV sets & $\begin{array}{l}\text { Television sets (per 1,000 peo- } \\
\text { ple) }\end{array}$ & $\begin{array}{l}\text { World } \\
(2006)\end{array}$ & Bank & Ross (2001) \\
\hline U.K. colony & $\begin{array}{l}1 \text { if ever in colonial relationship } \\
\text { with United Kingdom }\end{array}$ & \multicolumn{2}{|c|}{ CEPII (2006) } & $\begin{array}{l}\text { Barro (1999); Boix } \\
\text { and Stokes (2003); } \\
\text { Clague et al. (2001); } \\
\text { Crenshaw (1995) }\end{array}$ \\
\hline $\begin{array}{l}\text { Urban popula- } \\
\text { tion }\end{array}$ & Urban population (\% of total) & $\begin{array}{l}\text { World } \\
(2006)\end{array}$ & Bank & $\begin{array}{lr}\text { Barro } & (1999) ; \\
\text { Nieswiadomy } & \text { and } \\
\text { Strazcich } & (2004) ; \\
\text { Ross (2001) } & \end{array}$ \\
\hline $\begin{array}{l}\text { World democ- } \\
\text { racy }\end{array}$ & Global share of democracies & $\begin{array}{l}\text { Own } \\
\text { tions }\end{array}$ & calcula- & $\begin{array}{l}\text { Boix and Stokes } \\
(2003) ; \quad \text { Gleditsch } \\
\text { and Ward (2006) }\end{array}$ \\
\hline
\end{tabular}

\section{Results}

The results of our empirical analysis are summarized in Tables 2 and 3 as well as Tables 6 and 7 in the Appendix. They read as follows: Median Beta gives the median coefficient estimate over all regressions of the coefficient for each variable (when included in the $F$ vector). Median S.E. gives the corresponding median standard error. \%Sig. gives the percentage of regressions in which the coefficient is statistically different from zero at the 5 percent level. $C D F(0)$ is the cumulative distribution function which reports the sum of the areas under the density function either above or below zero (which ever area is larger, as described above). All variables are sorted according to this last criterion. The cutoff point for a variable to be considered robustly linked to our dependent variable, following Sala-i-Martin (1997), is a $\operatorname{CDF}(0)$ value of 0.9 or higher. Regres. represents the number of regressions run for each variable tested, and Avg. Obs. reports the average number of observations for these regressions.

Table 2 contains the significant results for the emergence of democracy (the insignificant results, of which there are many, are reported in the Appendix, Table 6). The first result to note is that GDP per capita does not explain democratic transitions. The very low value 
Table 2: Results EBA - transition from autocracy to democracy (robust variables)

\begin{tabular}{lrrrrrr}
\hline Variable & $\begin{array}{r}\text { Median } \\
\text { Beta }\end{array}$ & $\begin{array}{r}\text { Median } \\
\text { S.E. }\end{array}$ & \%Sig. & CDF(0) & Regres. & $\begin{array}{r}\text { Avg. } \\
\text { Obs. }\end{array}$ \\
\hline \hline Base Model & & & & & & \\
GDP p.c., PPP (log) & -0.166 & 0.360 & 12.8 & 0.6041 & 32,558 & 894 \\
& & & & & & \\
Extended Model & & & & & & \\
Number of past transitions & 0.535 & 0.207 & 87.5 & 0.9750 & 30,708 & 887 \\
OECD member & 2.359 & 0.986 & 82.1 & 0.9673 & 28,263 & 939 \\
Muslim share & -2.112 & 1.235 & 68.9 & 0.9494 & 30,860 & 820 \\
Fuel exports & -0.058 & 0.041 & 67.5 & 0.9472 & 30,758 & 543 \\
GDP growth & -0.064 & 0.041 & 65.0 & 0.9267 & 30,900 & 878 \\
\hline
\end{tabular}

Notes: 'Median Beta' and 'Median S.E.' give the median over all regressions of the coefficient and the standard error, respectively. '\%Sig.' denotes the percentage of regressions in which the respective coefficient is statistically significant at the five percent level. 'CDF(0)' yields the result of the CDF criterion as described in the previous section. All variables are sorted according to this criterion. The cut-off value for a variable to be considered robustly linked to our dependent variable is 0.9. Finally, 'Regres.' and 'Avg. Obs.' report the number of regressions run for testing each variable and the average number of observations for each regression. The results are derived using logistic regressions conditional on being autocratic the year before.

of the $\operatorname{CDF}(0)$ indicates that this result is not even a "borderline" variable. This confirms the Przeworski et al. (2000) critique of the modernization theory literature.

Turning to the other variables, we see that the variable with the highest score on the CDF criterion is the number of previous transitions. Having had past experience with regime transitions increases the probability of democracy emerging again. One could interpret this as a learning effect.

Being an OECD member also increases the likelihood of a change towards a democracy. We include this variable following Ross (2001) and confirm his finding. It also confirms Pevehouse's (2002a,b) idea that membership in democratic international organizations increases the probability of a transition to democracy. The OECD espouses democracy explicitly and members pressure one another to follow democratic values. ${ }^{12}$

We find that democratic transitions are less likely in Islamic countries, as measured by the (time-invariant) percentage of the population that is Muslim. We are not convinced

\footnotetext{
${ }^{12}$ There are five cases in which OECD members experienced a transition to democracy: Greece 1974, Portugal 1976, Spain 1977, Turkey 1983 and Mexico 2000. Considering that transitions to democracy are not common (there are 79 of them in the data), this number is notable.
} 
from this finding that Islam is incompatible with democracy. Turkey is a notable example. One possibility is that several Muslim countries are fuel exporters. We find the larger the share of fuel exports, the less likely a country is to become a democracy. This is in part driven by the Arabic oil-producing countries which all have a long non-democratic tradition. The finding is consistent with the resource-curse literature (e.g., Ross, 2001; Jensen and Wantchekon, 2004). The share of Muslims and fuel exports findings require further investigation which we undertake below.

The final variable fulfilling the CDF criterion is annual GDP growth. Countries that perform better economically are less likely to see democracy emerge. In good times, the "need" for a change might not be felt in the population, and autocratic rulers can justify their position. This may seem intuitive, but it defies a basic idea in modernization theory that as a country develops, democracy should become more likely. Economic growth is good for the survival of dictatorships. No other variable tested passes the CDF criterion (see Appendix Table 6).

Table 3 presents the significant results for the survival of democracy. Again, insignificant results, of which there are many, are presented in the Appendix, Table 7.

GDP per capita plays a central role. Richer countries are more likely to remain democracies. This confirms the findings in the previous literature. It is perhaps the most agreed upon finding in the literature, and we confirm the consensus. Development is good for the survival of democracy.

Of the remaining variables, we find that having a (former) military leader to have the strongest performance according to the CDF criterion. The result implies that democracies that have a leader with a military background have a lower probability of sustaining a democracy. This confirms the argument of Cheibub (2006). ${ }^{13}$

The next strongest performer is the neighboring democracy variable. This indicates that there are positive spillover effects from democracies as the probability of remaining a democracy increases in the number of democratic neighbors. This confirms the arguments of Gleditsch (2002).

Finally, a very interesting result is the effect of previous transitions, which is the only

\footnotetext{
${ }^{13}$ For a formal argument as to why, see Acemoglu et al. (2008b).
} 
Table 3: Results EBA - remaining a democracy (robust variables)

\begin{tabular}{lrrrrrr}
\hline Variable & $\begin{array}{r}\text { Median } \\
\text { Beta }\end{array}$ & $\begin{array}{r}\text { Median } \\
\text { S.E. }\end{array}$ & \%Sig. & CDF(0) & Regres. & $\begin{array}{r}\text { Avg. } \\
\text { Obs. }\end{array}$ \\
\hline \hline Base Model & & & & & & \\
GDP p.c., PPP (log) & 1.504 & 0.953 & 68.6 & 0.9285 & 31,316 & 1,014 \\
& & & & & & \\
Extended Model & & & & & & \\
Military Leader & -2.590 & 1.657 & 77.1 & 0.9558 & 22,181 & 836 \\
Neighboring democracies & 2.903 & 1.999 & 49.4 & 0.9294 & 27,681 & 821 \\
Number of past transitions & -0.630 & 0.497 & 59.2 & 0.9140 & 29,012 & 1,020 \\
\hline
\end{tabular}

Notes: See notes to Table 2 for the explanation of the abbreviations used. The results are derived using logistic regressions conditional on being democratic the year before.

variable that passes the CDF criterion in both models. Previous transitions increase the chances of democratic failure. Taking the result of Table 2 also into account, we can summarize that previous transitions increase the instability of the political system. All remaining variables fail to pass the CDF criterion.

\section{Extensions}

Regime transitions are rare events. Thus, it really should not be surprising that few variables are correlated with them. Indeed, once a variable has been identified as a robust predictor of regime transition, there may be little variation left to explain. With this in mind, we put our variables that have survived so far to a final set of tests - to see if their robustness ultimately holds up. We proceed to analyze a final set of specifications that pit the most robust predictors up against one another. Recall that with little consensus in the literature, we conservatively placed only GDP per capita in all 3 million regressions analyzed above. The variables that survived the EBA did so controlling for GDP per capita and up to only three other variables at a time. This was already too much for most of the variables we considered, so all of the variables that have survived so far are noteworthy. But with little variation to explain, it is not obvious that the surviving variables will survive 
when pitted exclusively against one another. So far, they have faced each other directly in only a handful of literally thousands of specifications, and the precise results have not been checked. We do this below. The results are presented in Tables 4 and 5 .

As one would expect, the majority of our variables performs well. For the emergence of democracy, the number of past transitions, OECD membership, and economic growth have the same significant effects reported above. Interestingly, however, the significance of Muslim share and fuel exports is weaker than one might expect following the EBA results. We return to this below.

As for the marginal effects, they are weak but understandable. Our model predicts that the baseline probability of a democratic transition is only 2 percent holding all our explanatory variables to their mean values. ${ }^{14}$ Given this low probability, it is actually quite remarkable that each additional prior transition increases this chance by roughly $1 \%$, while each percentage point of GDP growth reduces this probability by roughly $0.1 \%$.

Now, to test whether our finding for the share of the population that is Muslim is really driven by oil, we re-analyze our final model excluding countries classified as oil exporters according to Easterly and Sewadeh (2001). ${ }^{15}$ The result is presented on the right hand side of Table 4 . We see that upon the exclusion of primary oil exporters the result for the Muslim share vanishes while all other results remain almost unchanged. We conclude that the Islam finding is actually driven by the coincidence of oil and Islam or some other fixed effect of these countries.

Regarding the survival of democracy, only GDP per capita and the number of past transitions have the expected significant effects, while military leader and neighboring democracy do not. So what is going on here?

The effect of military leader turns out to depend on three cases in our estimation sample where democracy breaks down under a chief executive who is a former military leader. ${ }^{16}$

\footnotetext{
${ }^{14}$ The unconditional transition probability in our sample is 2.1 percent.

${ }^{15}$ In the sample of our final model these are: Algeria, Bahrain, Gabon, Indonesia, Iran, Kuwait, Nigeria, Oman, Saudi Arabia, United Arab Emirates. Note that Easterly and Sewadeh classify countries as oil exporters if more than $50 \%$ of total exports of goods and services come from fuels (to be precise, fuels listed under the Standard International Trade Classification category 3 - mineral fuels, lubricants and related materials), so the remaining countries include some that have positive oil exports. Hence we can include our fuel exports variable.

${ }^{16}$ The cases are Guatemala 1982, Thailand 1991, and Sierra Leone 1997.
} 
The variable survives EBA analysis, but does not survive a particular specification which includes the number of past transitions (of course, number of past transitions was included in some of the regressions of the EBA, but not all). The reason for this is quite easy to see when one scrutinizes the data. Number of past transitions explains all three of the cases that military leader explains, and also explains further cases. ${ }^{17}$

With neighboring democracy, the results also appear to be disappointing at first. Recall from Table 3 that while most of the mass of the cumulative distribution function, $\operatorname{CDF}(0)$, is positive (0.9294), the coefficient is significant at the $5 \%$ level in only 49.4 percent of the regressions analyzed. So, for about half of the regressions, neighboring democracy is not significant at conventional levels. It turns out that the specifications that include military leader are among those where neighboring democracy is not significant. Nevertheless, we still consider this variable to be among the more robust determinants of the survival of democracy. Indeed, when we remove the military leader variable (which itself is not significant in the presence of the number of transitions variable), neighboring democracy obtains a positive significant effect.

Regarding marginal effects, the probability of remaining a democracy is (at the mean of our variables) 99.8 percent. ${ }^{18}$ This explains why basically all marginal effects in the first specification presented in Table 5 are insignificant except for GDP per capita. Note, however, that once the military leader variable is removed from the specification, the marginal effects for all variables become more significant (the weakest is the effect of neighboring democracies, which is borderline significant at the 0.10 level). Considering the rarity of democracy breakdowns, we are most impressed by the significance of these marginal effects.

Looming large over what we have done here, however, is precisely the question of rare events. Although ignored, as far as we know, by the transitions literature, there remains the issue of whether the analysis should be adjusted because regime transitions are rare events. As shown by King and Zeng (2001), using standard logit regressions in such a

\footnotetext{
${ }^{17}$ Democracy breaks down when sum of past transitions is greater than 0 in nine cases: Argentina 1976, Pakistan 1977, Ghana 1981, Guatemala 1982, Nigeria 1983, Sudan 1989, Peru 1990, Thailand 1991, and Sierra Leone 1997.

${ }^{18}$ The unconditional survival probability in our sample is 98.2 percent.
} 
setting might lead to an estimation bias. To check the robustness of our results we analyze our final model specifications using the implementation of the rare events logistic regression module provided by Tomz et al. (1999). It turns out that our findings do not depend on the estimator we employ. Using the rare events estimator, our predicted probability of a transition from autocracy to democracy changes from 2.04 percent to 2.21 percent, and significance levels of the effects of the individual variables are not affected. For the survival of democracy, the probability changes from 99.82 percent to 99.74 percent, and - again - the significance levels of the effects of the individual variables are not affected. These results are available on request.

Table 4: Final models - transition from autocracy to democracy

\begin{tabular}{lllll}
\hline Variable & Coefficient & $\begin{array}{l}\text { Marginal } \\
\text { Effect }\end{array}$ & Coefficient & $\begin{array}{l}\text { Marginal } \\
\text { Effect }\end{array}$ \\
\hline \hline Number of past transitions & 0.5542 & 0.0111 & 0.5383 & 0.0131 \\
& $(5.05)^{* * *}$ & $(4.10)^{* * *}$ & $(4.82)^{* * *}$ & $(4.22)^{* * *}$ \\
OECD member & 1.1230 & 0.0386 & 1.0909 & 0.0443 \\
Muslim share & $(2.19)^{* *}$ & $(1.40)$ & $(2.12)^{* *}$ & $(1.40)$ \\
Fuel exports & -1.1606 & -0.0232 & -1.0022 & -0.0244 \\
& $(1.91)^{*}$ & $(2.06)^{* *}$ & $(1.56)$ & $(1.64)$ \\
GDP growth & -0.0066 & -0.0001 & -0.0117 & -0.0003 \\
& $(0.86)$ & $(0.87)$ & $(0.89)$ & $(0.91)$ \\
Constant & -0.0711 & -0.0014 & -0.0579 & -0.0014 \\
& $(2.69)^{* * *}$ & $(2.70)^{* * *}$ & $(1.96)^{* *}$ & $(1.97)^{* *}$ \\
\hline Observations & -3.2960 & & -3.3072 & \\
Pseudo R-squared & $(13.28)^{* * *}$ & & $(12.69)^{* * *}$ & \\
Predicted Probability & 1,464 & & 1,233 & \\
\hline
\end{tabular}

Notes: The table shows the logistic regressions including the variables which passed the CDF criterion. On the left all countries are included, on the right we exclude the countries coded as oil exporters by Easterly and Sewadeh (2001). The marginal Effect is given in the respective column. It is calculated at the sample mean of each variable. The predicted probability gives the probability predicted by the model for a transition from autocracy to democracy if all variables are assigned their mean value. */**/*** indicates significance at the 10/5/1-\% level; absolute t-values are given in parentheses. 
Table 5: Final models - remaining a democracy

\begin{tabular}{lllll}
\hline Variable & Coefficient & $\begin{array}{l}\text { Marginal } \\
\text { Effect }\end{array}$ & Coefficient & $\begin{array}{l}\text { Marginal } \\
\text { Effect }\end{array}$ \\
\hline \hline GDP p.c., PPP (log) & 1.8440 & 0.0033 & 1.3239 & 0.0033 \\
& $(3.78)^{* * *}$ & $(1.61)^{*}$ & $(3.75)^{* * *}$ & $(2.10)^{* *}$ \\
Military leader & -0.8219 & -0.0022 & & \\
& $(1.04)$ & $(0.65)$ & & \\
Neighboring democracies & 1.3768 & 0.0025 & 1.8801 & 0.0046 \\
& $(1.17)$ & $(0.99)$ & $(2.01)^{* *}$ & $(1.60)$ \\
Number of past transitions & -0.7277 & -0.0013 & -0.6198 & -0.0015 \\
& $(2.39)^{* *}$ & $(1.54)$ & $(2.67)^{* * *}$ & $(1.87)^{*}$ \\
Constant & -9.8800 & & -6.3225 & \\
& $(3.07)^{* * *}$ & & $(2.66)^{* * *}$ & \\
\hline Observations & 966 & & 1,374 & \\
Pseudo R-squared & 0.3060 & & 0.2568 & \\
Predicted probability & 0.9982 & & 0.9975 & \\
\hline
\end{tabular}

Notes: The table shows the logistic regressions including the variables which passed the CDF criterion. The marginal effect is given in the respective column. The marginal effects were calculated at the sample means of each variable. The predicted probability gives the probability predicted by the model for a democracy to remain a democracy if all variables are assigned their mean value.

*/**/** indicates significance at the 10/5/1-\% level; absolute t-values are given in parentheses.

\section{Conclusions}

We consider 59 variables that have been proposed as determinants of democracy. Using dynamic logit regressions in combination with the extreme bounds analysis, we test the robustness of these factors as determinants of both the emergence and survival of democracy, which we define, following Schumpeter (1942) as the political system that determines leadership through contested elections.

We find a humbling result: only five variables robustly determine the emergence of democracy while just four are reliable predictors of the survival of democracy. One central variable proposed is GDP per capita. Contrary to modernization theory, we find that richer countries are not more likely to become democratic. They are, however, more likely to remain democracies. Both findings are in line with Przeworski et al. (2000). The other key finding is that previous political transitions facilitate future changes. This finding explains 
the frequent changes in the political landscape of Latin America. We find that previous transitions on the one hand increase the likelihood of a move towards democratization but on the other hand reduce the survival probability. Learning cuts both ways: people learn how to set up democracy but also how to subvert it (Przeworski et al. 2000). We have an interesting finding for economic growth: it makes dictatorships more likely to survive and lowers the chances for democracy to emerge. This stands in contrast to modernization theory. Instead, association with other democracies in the OECD appears to have facilitated democratic transitions. Having democracies as neighboring countries, in turn, increases the chances that democracy survives. The additional variables that may help to explain democratic transitions are not quite as robust: Muslim share and fuel export share (which lower the probability of democracy emerging), and having a former military leader as the chief executive (which lowers the survival rate of democracy). The most dubious of these appears to be Muslim share, whose effect disappears when oil producing countries are removed from the sample. The military leader finding is highly co-linear with the number of past transitions findings, so, while it may have an effect, the past transitions variable trumps it.

Our standard of robustness is a strong one: a version of Leamer's (1983) extreme bounds analysis. Other variables that we test may be significant in specific theoretical models, but they do not survive the rigors of our tests. This does not imply that they are unimportant, but it does imply that the variables that do survive may be the most important factors on which to base policy, since we can be most certain of their effects.

So what policy conclusions we can draw from our analysis? First of all, regime transitions are rare, and most policies variables do not have a robustly systematic impact. Indeed, most of the handful of variables we do find significant are beyond the control of policymakers. Yet, international organizations and Western countries often want to support democratization processes around the world. Our results imply that giving aid or other forms of transfers in order to increase a country's wealth might not be a good idea prior to a democratic transition. Only after a country democracy has been established can such assistance be beneficial for the promotion of democracy. Efforts may be best spent by targeting poor democracies. Short-term growth, however, is not the solution. Only 
sustained development can help democracy survive. This calls for a serious commitment to poor democracies. Transfers should be designed to help make the payoffs for complying with the rules of democracy more lucrative than the payoffs from subverting the regime. 


\section{Appendix}

Table 6: Results EBA - transition from autocracy to democracy (non-robust variables)

\begin{tabular}{|c|c|c|c|c|c|c|}
\hline Variable & $\begin{array}{r}\text { Median } \\
\text { Beta }\end{array}$ & $\begin{array}{r}\text { Median } \\
\text { S.E. }\end{array}$ & \%Sig. & $\mathrm{CDF}(0)$ & Regres. & $\begin{array}{l}\text { Avg. } \\
\text { Obs. }\end{array}$ \\
\hline Openness & -0.014 & 0.012 & 57.1 & 0.8969 & 30,889 & 852 \\
\hline Military expenditure & -0.371 & 0.232 & 47.5 & 0.8859 & 30,847 & 377 \\
\hline European settlers 1900 & 0.021 & 0.016 & 64.1 & 0.8854 & 30,872 & 837 \\
\hline Military leader & 0.913 & 0.589 & 61.4 & 0.8833 & 30,601 & 754 \\
\hline French colony & -0.877 & 0.677 & 33.2 & 0.8778 & 28,782 & 934 \\
\hline GDP p.c. growth & -0.041 & 0.043 & 55.5 & 0.8706 & 30,900 & 877 \\
\hline Spanish colony & 0.976 & 0.720 & 52.7 & 0.8602 & 29,761 & 909 \\
\hline FDI net inflows & -0.109 & 0.098 & 37.0 & 0.8574 & 30,893 & 850 \\
\hline Spanish speaking & 1.014 & 0.729 & 51.8 & 0.8570 & 29,801 & 909 \\
\hline Latin America & 0.912 & 0.725 & 54.6 & 0.8505 & 29,758 & 849 \\
\hline Population (log) & 0.194 & 0.172 & 37.6 & 0.8399 & 30,895 & 882 \\
\hline Employment in agriculture & 0.026 & 0.035 & 25.6 & 0.8394 & 30,790 & 233 \\
\hline Service employment, male & -0.036 & 0.070 & 9.1 & 0.8232 & 30,640 & 181 \\
\hline Neighboring democracies & 0.922 & 0.849 & 48.6 & 0.8204 & 30,890 & 823 \\
\hline Portuguese speaking & 1.487 & 0.950 & 18.0 & 0.8188 & 22,758 & 1,088 \\
\hline Colony & -0.922 & 0.711 & 38.5 & 0.8055 & 29,956 & 845 \\
\hline Population share $65+$ & 0.131 & 0.232 & 48.3 & 0.8034 & 30,888 & 877 \\
\hline Oil exporter & -1.119 & 0.919 & 27.9 & 0.8014 & 26,309 & 920 \\
\hline Literacy & 0.015 & 0.016 & 30.1 & 0.7968 & 30,882 & 756 \\
\hline World democracy & 2.931 & 3.345 & 44.3 & 0.7900 & 30,864 & 883 \\
\hline IO score & 0.045 & 0.064 & 42.0 & 0.7858 & 30,773 & 768 \\
\hline French speaking & -0.622 & 0.676 & 13.4 & 0.7822 & 29,142 & 925 \\
\hline Military personnel & 0.000 & 0.000 & 4.2 & 0.7765 & 30,909 & 435 \\
\hline Settler mortality (log) & 0.365 & 0.403 & 19.4 & 0.7759 & 30,712 & 628 \\
\hline Population share 0-14 & -0.032 & 0.115 & 31.8 & 0.7661 & 30,889 & 877 \\
\hline Tax revenue & 0.042 & 0.085 & 16.7 & 0.7468 & 30,350 & 212 \\
\hline IO score, change & 0.019 & 0.222 & 27.3 & 0.7411 & 30,589 & 770 \\
\hline Bonds investment & 0.000 & 0.000 & 8.9 & 0.7225 & 30,903 & 786 \\
\hline Socialist & -0.366 & 0.757 & 13.0 & 0.7112 & 26,998 & 870 \\
\hline Life expectancy & 0.071 & 0.085 & 12.0 & 0.7021 & 30,489 & 262 \\
\hline Service employment, female & -0.013 & 0.036 & 3.9 & 0.7012 & 30,728 & 181 \\
\hline Population share 15-64 & 0.034 & 0.130 & 18.4 & 0.6968 & 30,890 & 877 \\
\hline Inequality & 0.048 & 0.082 & 9.0 & 0.6782 & 30,632 & 475 \\
\hline Telephone mainlines & -0.005 & 0.010 & 3.4 & 0.6634 & 30,900 & 857 \\
\hline Africa & -0.269 & 0.684 & 13.0 & 0.6615 & 30,727 & 827 \\
\hline
\end{tabular}




\begin{tabular}{|c|c|c|c|c|c|c|}
\hline Variable & $\begin{array}{r}\text { Median } \\
\text { Beta }\end{array}$ & $\begin{array}{r}\text { Median } \\
\text { S.E. }\end{array}$ & \%Sig. & $\mathrm{CDF}(0)$ & Regres. & $\begin{array}{l}\text { Avg. } \\
\text { Obs. }\end{array}$ \\
\hline Land area & 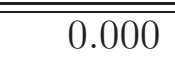 & 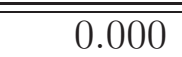 & 3.7 & 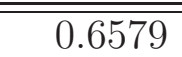 & 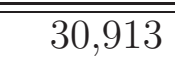 & $\overline{878}$ \\
\hline Metal exports & 0.009 & 0.032 & 3.5 & 0.6534 & 30,615 & 572 \\
\hline Portuguese colony & -0.060 & 0.938 & 3.7 & 0.6279 & 22,121 & 1,095 \\
\hline U.K. colony & -0.153 & 0.516 & 7.0 & 0.6253 & 30,801 & 884 \\
\hline Infant mortality & -0.009 & 0.274 & 0.4 & 0.6141 & 30,301 & 170 \\
\hline OPEC member & 0.042 & 0.831 & 10.1 & 0.6131 & 26,452 & 986 \\
\hline Portfolio investment & 0.000 & 0.000 & 0.0 & 0.6104 & 30,910 & 725 \\
\hline Arable land & 0.000 & 0.000 & 17.3 & 0.5989 & 30,913 & 878 \\
\hline TV sets & -0.001 & 0.013 & 3.7 & 0.5975 & 30,898 & 845 \\
\hline Income taxes & 0.010 & 0.055 & 4.0 & 0.5882 & 30,395 & 210 \\
\hline Industry employment, female & -0.018 & 0.058 & 0.1 & 0.5819 & 30,769 & 180 \\
\hline Middle East & -0.164 & 0.699 & 1.8 & 0.5805 & 28,785 & 870 \\
\hline Globalization & -0.004 & 0.034 & 7.0 & 0.5772 & 30,845 & 722 \\
\hline Urban population & 0.004 & 0.019 & 3.8 & 0.5741 & 30,886 & 871 \\
\hline Industry employment, male & -0.025 & 0.066 & 3.6 & 0.5377 & 30,619 & 181 \\
\hline English speaking & 0.016 & 0.517 & 2.9 & 0.5254 & 30,743 & 886 \\
\hline Inflation & 0.004 & 0.016 & 14.0 & 0.5220 & 30,874 & 865 \\
\hline Equity investment & 0.000 & 0.000 & 4.3 & 0.5026 & 30,885 & 816 \\
\hline
\end{tabular}

Notes: See notes to Table 2 for the explanation of the abbreviations used. The results are derived using logistic regressions conditional on being autocratic the year before. 
Table 7: Results EBA - remaining a democracy (non-robust variables)

\begin{tabular}{|c|c|c|c|c|c|c|}
\hline Variable & $\begin{array}{r}\text { Median } \\
\text { Beta }\end{array}$ & $\begin{array}{r}\text { Median } \\
\text { S.E. }\end{array}$ & \%Sig. & $\mathrm{CDF}(0)$ & Regres. & $\begin{array}{l}\text { Avg. } \\
\text { Obs. }\end{array}$ \\
\hline Colony & 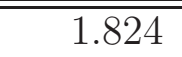 & 1.238 & 52.5 & 0.8884 & 27,970 & 965 \\
\hline GDP p.c. growth & 0.094 & 0.133 & 51.3 & 0.8159 & 29,278 & 1,009 \\
\hline Openness & 0.022 & 0.178 & 38.5 & 0.8114 & 29,361 & 1,004 \\
\hline English speaking & 0.864 & 1.000 & 25.1 & 0.8090 & 27,983 & 1,039 \\
\hline Telephone mainlines & 0.031 & 0.513 & 0.8 & 0.8065 & 29,178 & 1,007 \\
\hline Muslim share & -0.718 & 2.730 & 33.7 & 0.7912 & 28,901 & 935 \\
\hline Industry employment, male & 0.267 & 0.298 & 0.3 & 0.7904 & 23,129 & 602 \\
\hline U.K. colony & 0.738 & 1.051 & 14.6 & 0.7846 & 27,980 & 1,039 \\
\hline Spanish colony & -0.876 & 1.079 & 15.0 & 0.7759 & 23,693 & 1,140 \\
\hline Bonds investment & 0.000 & 0.000 & 0.1 & 0.7702 & 30,360 & 579 \\
\hline Industry employment, female & 0.191 & 0.300 & 0.1 & 0.7701 & 26,406 & 568 \\
\hline GDP growth & 0.022 & 0.143 & 47.5 & 0.7693 & 29,244 & 1,010 \\
\hline Population share $65+$ & 0.353 & 0.697 & 0.3 & 0.7558 & 29,420 & 982 \\
\hline Infant mortality & -0.007 & 0.305 & 0.4 & 0.7447 & 21,627 & 413 \\
\hline Service employment, female & 0.081 & 0.274 & 0.2 & 0.7419 & 24,304 & 594 \\
\hline Spanish speaking & -0.731 & 1.141 & 7.5 & 0.7406 & 23,692 & 1,140 \\
\hline IO score, change & 0.390 & 0.608 & 0.6 & 0.7384 & 26,107 & 752 \\
\hline French colony & 0.619 & 0.986 & 7.0 & 0.7371 & 20,309 & 1,150 \\
\hline Tax revenue & 0.256 & 0.442 & 0.2 & 0.7342 & 21,504 & 311 \\
\hline World democracy & 0.741 & 7.494 & 38.3 & 0.7294 & 29,324 & 1,012 \\
\hline Inequality & -0.163 & 0.209 & 3.3 & 0.7220 & 26,598 & 685 \\
\hline Military expenditure & -0.172 & 0.421 & 1.2 & 0.7157 & 28,761 & 559 \\
\hline IO score & -0.007 & 0.282 & 2.5 & 0.7056 & 27,054 & 744 \\
\hline Middle East & -0.976 & 1.314 & 5.8 & 0.6972 & 26,138 & 1,008 \\
\hline Inflation & 0.085 & 0.173 & 20.3 & 0.6967 & 29,599 & 996 \\
\hline Arable land & 0.000 & 0.000 & 5.0 & 0.6902 & 30,489 & 960 \\
\hline Population (log) & -0.354 & 0.477 & 4.7 & 0.6867 & 29,182 & 1,015 \\
\hline OECD member & -0.664 & 1.249 & 2.9 & 0.6786 & 15,225 & 1,352 \\
\hline Income taxes & 0.017 & 0.386 & 1.3 & 0.6783 & 21,947 & 300 \\
\hline FDI net inflows & 0.116 & 0.231 & 0.2 & 0.6654 & 29,419 & 978 \\
\hline Urban population & 0.042 & 0.087 & 5.2 & 0.6622 & 29,174 & 1,013 \\
\hline Fuel exports & 0.461 & 0.533 & 0.1 & 0.6608 & 28,233 & 898 \\
\hline Military personnel & 0.000 & 0.007 & 3.3 & 0.6437 & 30,401 & 633 \\
\hline Employment in agriculture & -0.049 & 0.369 & 2.8 & 0.6431 & 23,979 & 683 \\
\hline Globalization & 0.003 & 0.079 & 0.7 & 0.6414 & 29,197 & 954 \\
\hline Metal exports & 0.714 & 0.795 & 11.2 & 0.6401 & 28,240 & 936 \\
\hline TV sets & 0.009 & 0.782 & 0.5 & 0.6393 & 29,737 & 989 \\
\hline
\end{tabular}




\begin{tabular}{lrrrrrr}
\hline Variable & $\begin{array}{r}\text { Median } \\
\text { Beta }\end{array}$ & $\begin{array}{r}\text { Median } \\
\text { S.E. }\end{array}$ & \%Sig. & CDF(0) & Regres. & $\begin{array}{r}\text { Avg. } \\
\text { Obs. }\end{array}$ \\
\hline \hline French speaking & -0.486 & 0.903 & 1.2 & 0.6316 & 20,550 & 1,144 \\
Life expectancy & -0.153 & 0.579 & 0.0 & 0.6145 & 20,474 & 494 \\
Population share 0-14 & -0.158 & 0.262 & 0.5 & 0.5929 & 29,484 & 981 \\
Literacy & 0.012 & 0.144 & 2.6 & 0.5888 & 29,100 & 616 \\
Land area & 0.000 & 0.000 & 0.8 & 0.5879 & 30,407 & 962 \\
Equity investment & 0.000 & 0.000 & 0.0 & 0.5842 & 30,210 & 586 \\
OPEC member & 0.737 & 1.286 & 10.1 & 0.5755 & 15,115 & 1,290 \\
Settler mortality (log) & -0.105 & 0.924 & 1.6 & 0.5752 & 28,785 & 589 \\
Oil exporter & -1.466 & 1.346 & 10.7 & 0.5672 & 15,124 & 1,202 \\
Portfolio investment & 0.000 & 0.000 & 0.0 & 0.5585 & 30,497 & 902 \\
Socialist & 0.062 & 1.192 & 0.1 & 0.5580 & 16,248 & 1,051 \\
European settlers 1900 & 0.006 & 0.026 & 0.4 & 0.5566 & 23,701 & 1,090 \\
Service employment, male & 0.013 & 0.153 & 0.9 & 0.5509 & 23,479 & 603 \\
Population share 15-64 & -0.169 & 0.350 & 0.7 & 0.5331 & 29,431 & 982 \\
Africa & -0.233 & 1.020 & 2.8 & 0.5083 & 22,400 & 1,038 \\
Latin America & 0.112 & 1.131 & 1.1 & 0.5027 & 23,691 & 1,059 \\
\hline
\end{tabular}

Notes: See notes to Table 2 for the explanation of the abbreviations used. The results are derived using logistic regressions conditional on being autocratic the year before. 
Table 8: Summary of previous empirical studies on the determinants of democracy

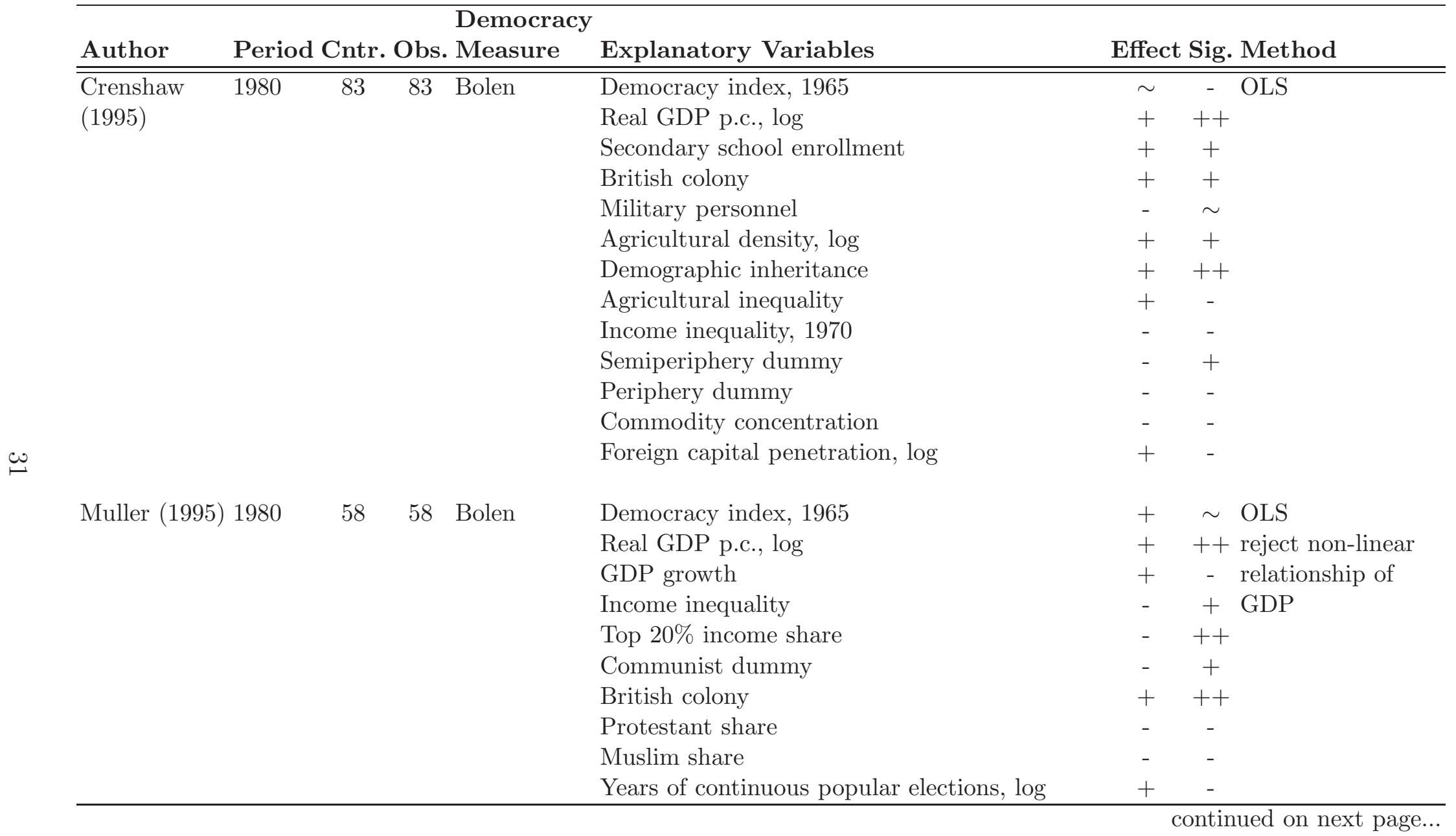




\begin{tabular}{|c|c|c|c|c|c|c|}
\hline \multirow{3}{*}{$\begin{array}{l}\text { Author } \\
\text { Barro (1999) }\end{array}$} & \multicolumn{4}{|c|}{ Democracy } & \multirow{2}{*}{\multicolumn{2}{|c|}{ Effect Sig. Method }} \\
\hline & Period & Cntr. Obs. & Measure & Explanatory Variables & & \\
\hline & $1960-1995$ & $103 \quad 103$ & Freedom & 5-year lag of dependent variable & + & +++ SUR \\
\hline & & & House & 10-year lag of dependent variable & + & + \\
\hline & & & & GDP, log & + & ++ \\
\hline & & & Bollen & Years of primary schooling & + & + \\
\hline & & & & Gap between male and female primary & - & ++ \\
\hline & & & & Urban population & - & + \\
\hline & & & & Population, log & + & $\sim$ \\
\hline & & & & Oil country dummy & - & ++ \\
\hline & & & & Life expectancy at birth, log & + & - \\
\hline & & & & Infant mortality rate & - & - \\
\hline & & & & Years of upper schooling & - & - \\
\hline & & & & Income inequality & - & - \\
\hline & & & & Share of middle class in income & + & - \\
\hline & & & & Educational inequality & - & - \\
\hline & & & & Ethnolinguistic fractionalization & - & + \\
\hline & & & & Rule-of-law index & + & - \\
\hline & & & & Former colony & - & - \\
\hline & & & & British colony & - & - \\
\hline & & & & French colony & - & - \\
\hline & & & & Spanish colony & + & - \\
\hline & & & & Portuguese colony & + & - \\
\hline & & & & Dummy for other colony & - & - \\
\hline & & & & Muslim share & - & - \\
\hline & & & & Protestant share & + & - \\
\hline & & & & Hindu share & + & - \\
\hline & & & & Buddhist share & + & - \\
\hline & & & & Miscellaneous eastern religion share & - & - \\
\hline & & & & Jewish share & + & - \\
\hline & & & & Nonreligion share & - & + \\
\hline & & & & Other religion share & - & - \\
\hline
\end{tabular}




\begin{tabular}{|c|c|c|c|c|c|}
\hline \multirow{3}{*}{$\begin{array}{l}\text { Author } \\
\overline{\text { Ross }(2001)}\end{array}$} & \multicolumn{3}{|c|}{ Democracy } & \multirow{2}{*}{\multicolumn{2}{|c|}{ Effect Sig. Method }} \\
\hline & Period & Cntr. Obs. Measure & Explanatory Variables & & \\
\hline & $1971-1997$ & $\begin{array}{ll}113 & 2,183 \text { Polity IV }\end{array}$ & 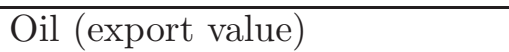 & 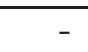 & $\overline{+++ \text { pooled OLS }}$ \\
\hline & & & Minerals (export value) & - & ++ \\
\hline & & & GDP & + & ++ \\
\hline & & & Muslim share & - & ++ \\
\hline & & & OECD dummy & + & ++ \\
\hline & & & Food (export value) & + & + \\
\hline & & & Agriculture (export value) & + & - \\
\hline & & & Large states & + & + \\
\hline & & & Mideast & - & ++ \\
\hline & & & Sub-Saharan Africa & - & ++ \\
\hline & & & Arabian Peninsula & - & ++ \\
\hline & & & Taxes & + & ++ \\
\hline & & & Government consumption & - & ++ \\
\hline & & & Government/GDP & - & ++ \\
\hline & & & Military expenditure & - & - \\
\hline & & & Military personnel & - & + \\
\hline & & & Ethnic tensions & - & - \\
\hline & & & Industry employment, male & + & ++ \\
\hline & & & Industry employment, female & + & ++ \\
\hline & & & Services employment, male & + & ++ \\
\hline & & & Services employment, female & - & ++ \\
\hline & & & Secondary enrollment, male & + & - \\
\hline & & & Secondary enrollment, female & + & - \\
\hline & & & Tertiary enrollment & - & - \\
\hline & & & Telephone mainlines & - & ++ \\
\hline & & & TV sets & - & - \\
\hline & & & Life expectancy & + & - \\
\hline & & & Urban population & - & - \\
\hline
\end{tabular}




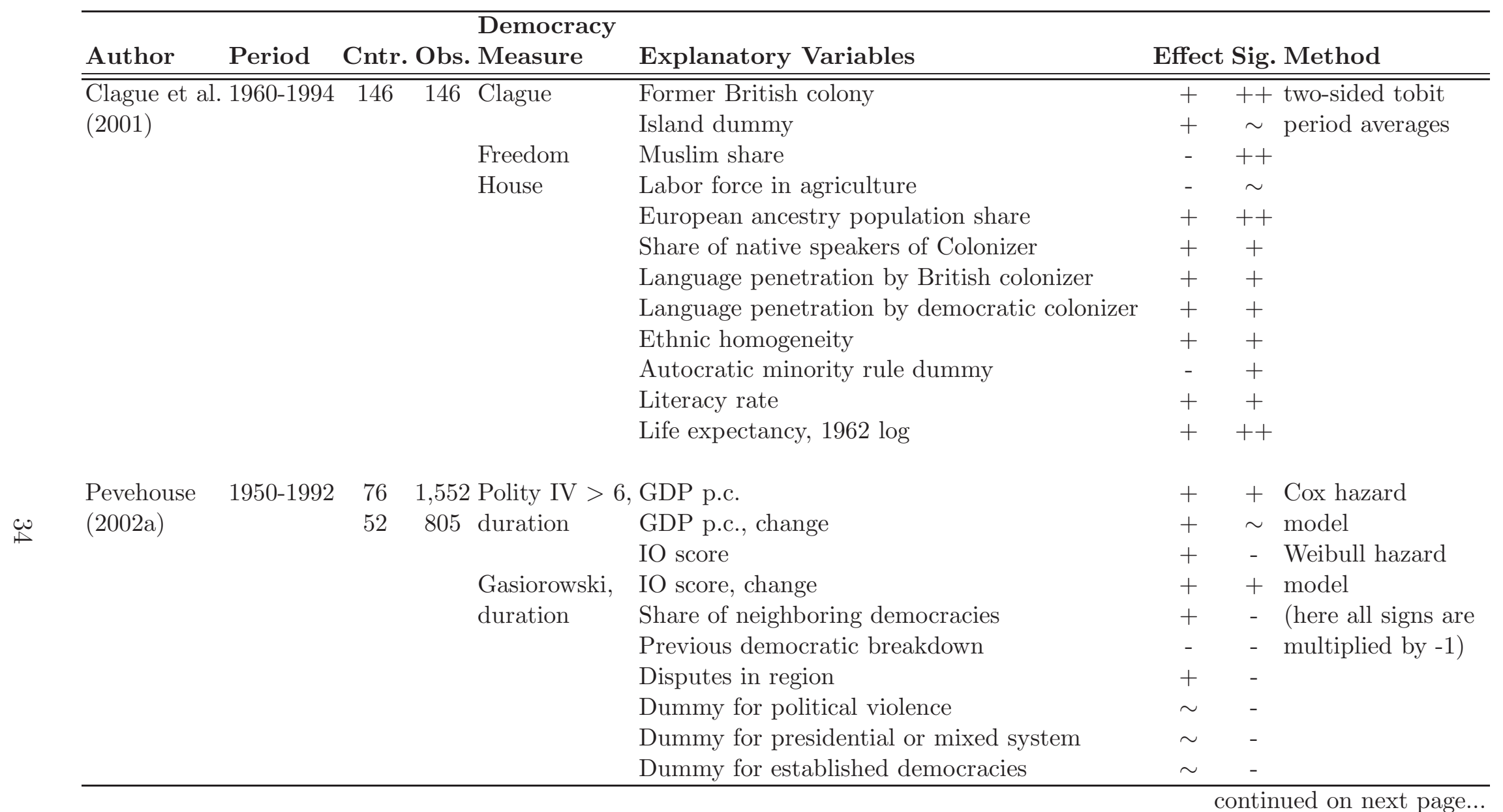




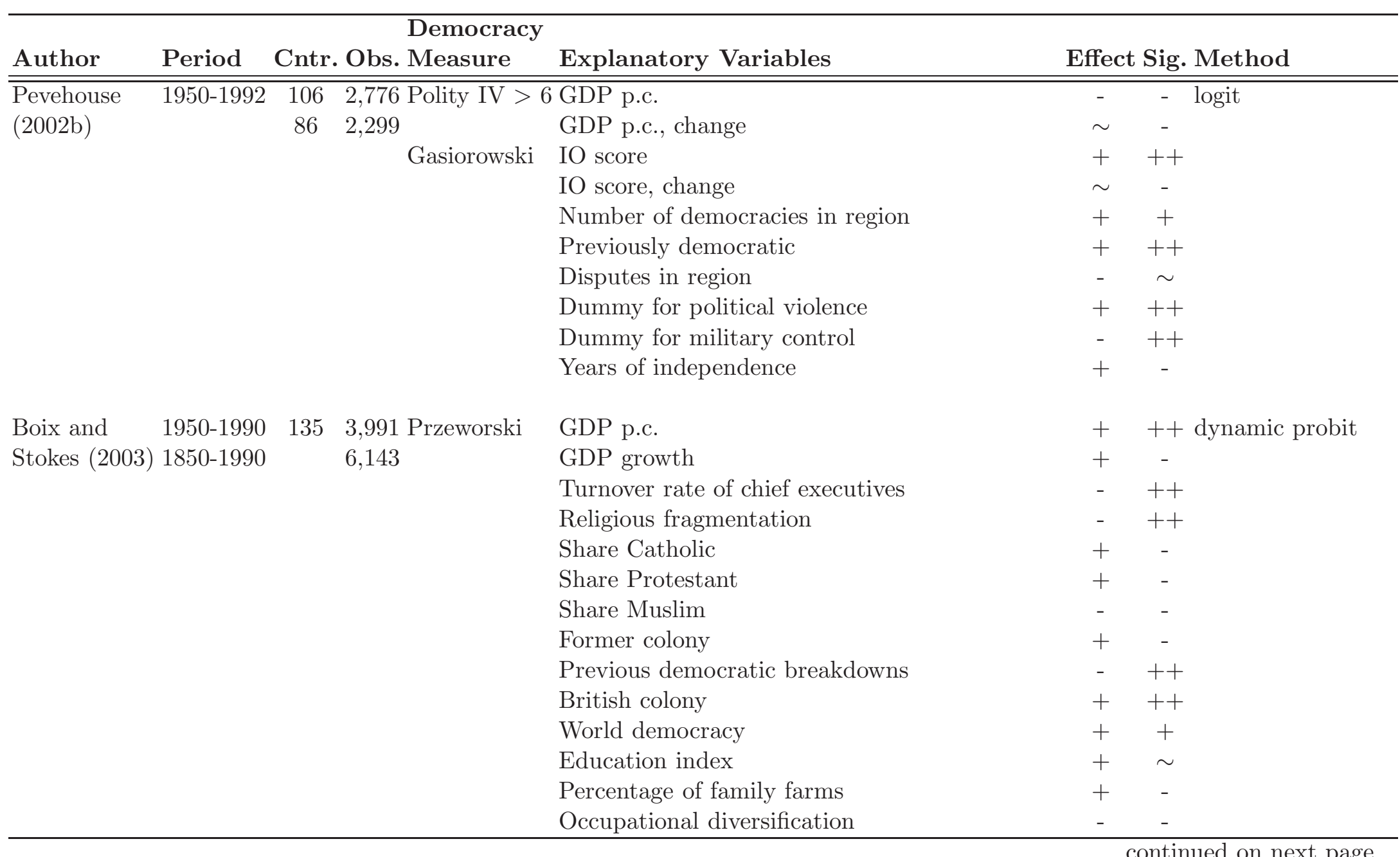




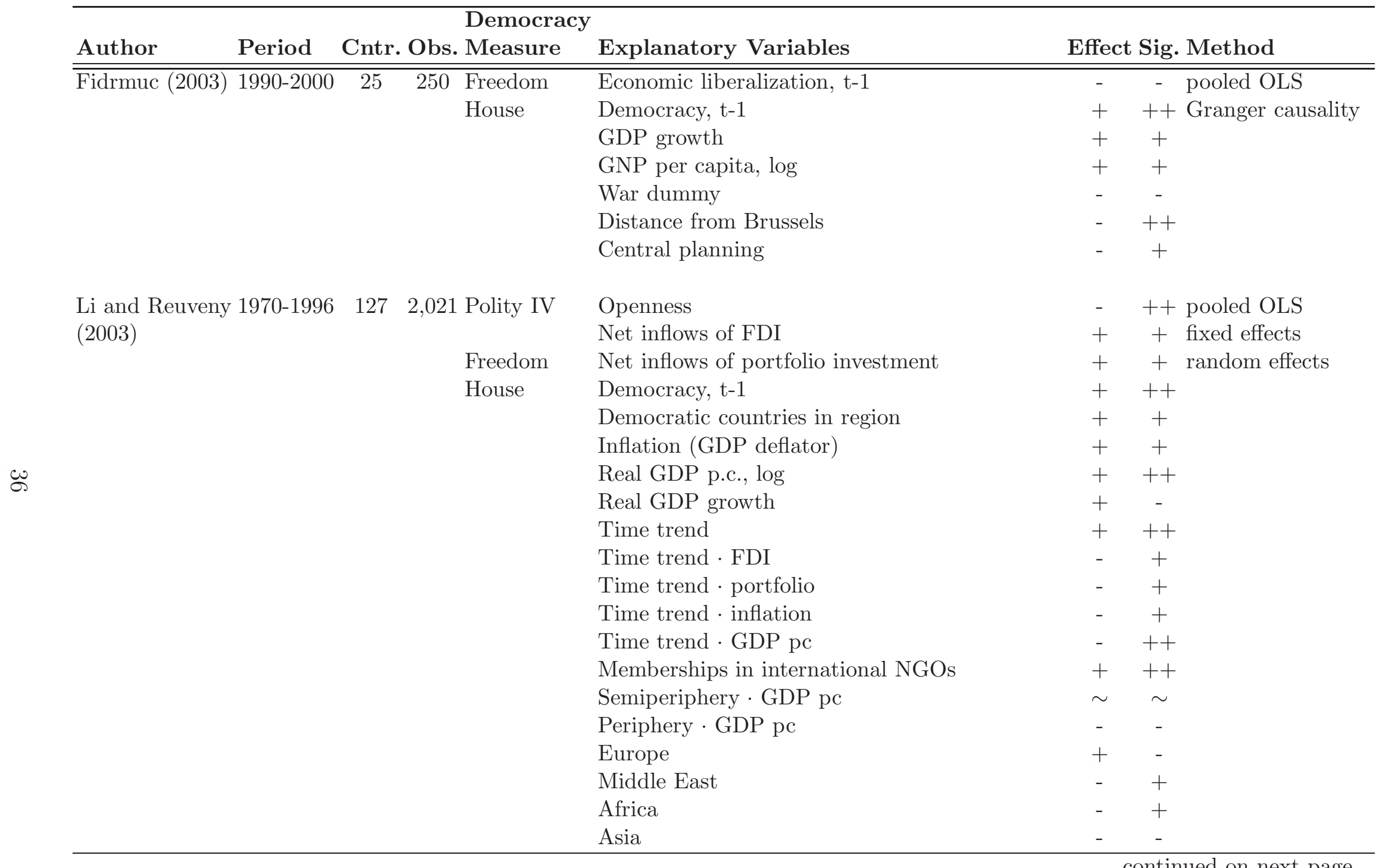




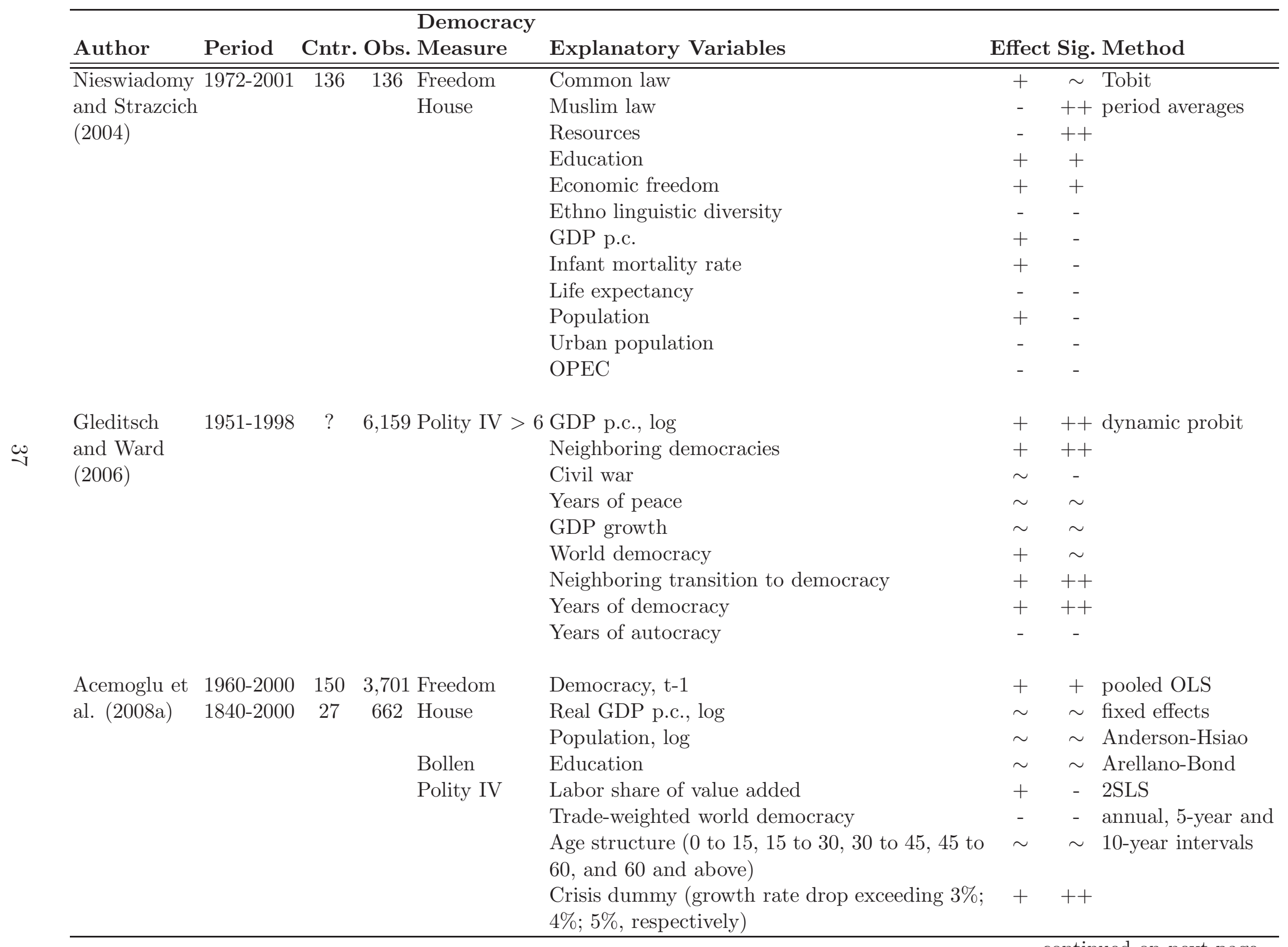




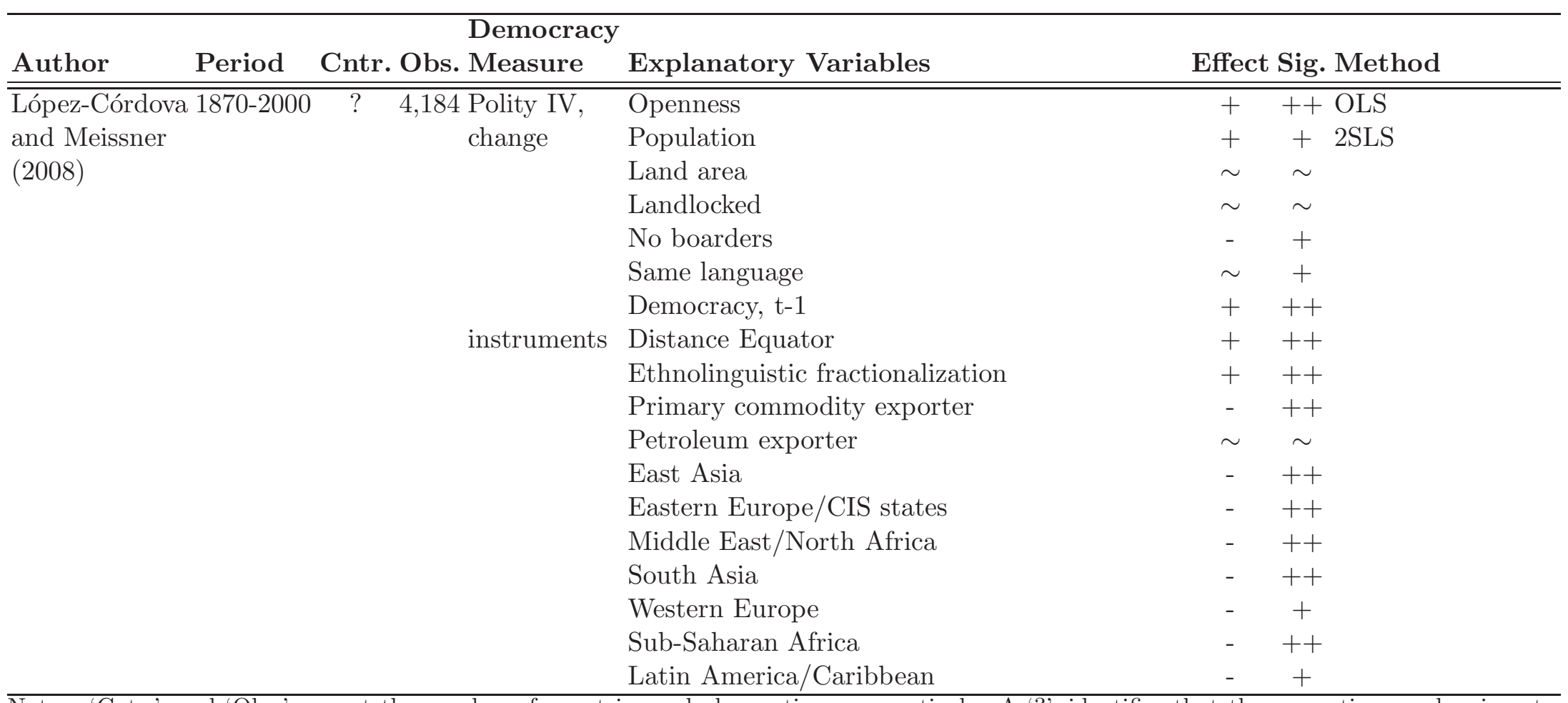

Notes: 'Cntr.' and 'Obs.' report the number of countries and observations, respectively. A '?' identifies that the respective number is not given in the study. 'Effect' yields the sign of the coefficient: $\sim$ indicates changing signs. 'Sig.' identifies the significance of each coefficient: ++ is significant at the $1 \%$ level, + significant at the $10 \%$ level, $\sim$ indicates changing significance level, i.e., sometimes significant sometimes not. 'Polity IV' stands for the democracy measure developed by Marshall and Jaggers (2000); 'Bollen' is taken from Bollen (1993), Clague corresponds to Clague et al. (1996), 'Freedom House' represents Freedom House (2006), 'Gasiorowski' refers to Gasiorowski (1996) and 'Przeworski' comes from Przeworski et al. (2000). 


\section{References}

Acemoglu, D., Johnson, S., Robinson, J. A., and Yared, P. (2008a). Income and democracy. American Economic Review, 98:808-842.

Acemoglu, D. and Robinson, J. A. (2006). Economic Origins of Dictatorship and Democracy. Cambridge University Press, New York.

Acemoglu, D., Ticchi, D., and Vindigni, A. (2008b). A theory of military dictatorships. Working Paper 13915, NBER.

Almond, G. and Verba, S. (1963). The Civic Culture. Princeton University Press, Princeton.

Barro, R. J. (1999a). Determinants of democracy. Journal of Political Economy, 107:S158S183.

Boix, C. (2003). Democracy and Redistribution. Cambridge University Press, New York.

Boix, C. and Stokes, S. C. (2003). Endogenous democratization. World Politics, 55:517549.

Bollen, K. A. (1993). Liberal democracy: Validity and method factors in cross-national measures. American Journal of Political Science, 37:1207-1230.

Centre d'Etudes Prospectives et d'Informations Internationales (CEPII) (2006). Distances database. Available at http://www.cepii.fr/anglaisgraph/bdd/distances.htm.

Cheibub, J. A. (2006). Presidentialism, Parliamentarism, and Democracy. Cambridge University Press, New York.

Cheibub, J. A., Gandhi, J., and Vreeland, J. R. (2008). Democracy and dictatorship revisited. Yale University, mimeo.

Clague, C., Gleason, S., and Knack, S. (2001). Determinants of lasting democracy in poor countries: Culture, development, and institutions. Annals of the American Academy of Political and Social Science, 573:16-41. 
Clague, C., Keefer, P., Knack, S., and Olson, M. (1996). Property and contract rights under autocracy and democracy. Journal of Economic Growth, 1:243-276.

Crenshaw, E. M. (1995). Democracy and demographic inheritance: The influence of modernity and proto-modernity on political and civil rights, 1965 to 1980. American Sociological Review, 60:702-718.

Dreher, A. (2006). Does globalization affect growth? Evidence from a new index of globalization. Applied Economics, 38:1091-1100.

Easterly, W. and Sewadeh, M. (2001). Global Development Network Growth Database. World Bank Economic and Development Research Group, Washington, D.C.

Elkins, Z. and Simmons, B. (2005). On waves, clusters, and diffusion: A conceptual framework. Annals of the American Academy of Political and Social Science, 598:33-51.

Fidrmuc, J. (2003). Economic reform, democracy and growth during post-communist transition. European Journal of Political Economy, 19:583-604.

Freedom House (2006). Freedom in the World 2006: The Annual Survey of Political Rights and Civil Liberties. Freedom House, Washington, D.C.

Freeman, J. R. and Quinn, D. (2008). The economic origins of democracy reconsidered. mimeo. Paper presented at the Annual Meeting of the American Political Science Association.

Gandhi, J. and Przeworski, A. (2006). Cooperation, cooptation, and rebellion under dictatorship. Economics \& Politics, 19:1-26.

Gasiorowski, M. J. (1996). An overview of the political regime change dataset. Comparative Political Studies, 29:469-483.

Gilardi, F. (2005). The institutional foundations of regulatory capitalism: The diffusion of independent regulatory agencies in Western Europe. Annals of the American Academy of Political and Social Science, 598:84-101. 
Gleditsch, K. S. (2002). All International Politics is Local: The Diffusion of Conflict, Integration, and Democratization. University of Michigan Press, Ann Arbor.

Gleditsch, K. S. and Ward, M. D. (2006). Diffusion and the international context of democratization. International Organization, 60:911-933.

Huntington, S. P. (1968). Political Order in Changing Societies. Yale University Press, New Haven.

Inglehart, R. (1988). The renaissance of political culture. American Political Science Review, 82:1203-1230.

Jensen, N. and Wantchekon, L. (2004). Resource wealth and political regimes in Africa. Comparative Political Studies, 37:816-841.

King, G. and Zeng, L. (2001). Logistic regression in rare events data. Political Analysis, 9:137-163.

Leamer, E. E. (1983). Let's take the con out of econometrics. American Economic Review, 73:31-43.

Levine, R. and Renelt, D. (1992). A sensitivity analysis of cross-county growth regressions. American Economic Review, 92:942-963.

Li, Q. and Reuveny, R. (2003). Economic globalization and democracy: An empirical analysis. British Journal of Political Science, 33:29-54.

Lipset, S. M. (1959). Some social requisites of democracy: Economic development and political legitimacy. American Political Science Review, 53:69-105.

López-Córdova, J. E. and Meisner, C. M. (2008). The impact of international trade on democracy: A long-run perspective. World Politics, 60:forthcoming.

Marshall, M. G. and Jaggers, K. (2000). Polity IV Project: Political regime characteristics and transitions, 1800-2000. Available at: http://www.cidcm.umd.edu/inscr/ polity/. 
Meseguer, C. (2005). Policy learning, policy diffusion, and the making of a new order. Annals of the American Academy of Political and Social Science, 598:67-82.

Muller, E. N. (1995). Economic determinants of democracy. American Sociological Review, 60:966-982.

Nieswiadomy, M. L. and Strazicich, M. C. (2004). Are political freedoms converging? Economic Inquiry, 42:323-340.

Organization for Economic Co-operation and Development (OECD) (2008). OECD webpage. Available at: http://www.oecd.org/.

Organization of the Petroleum Exporting Countries (OPEC) (2008). OPEC webpage. Available at: http://www.opec.org/.

Pevehouse, J. C. (2002a). With a little help from my friends? Regional organizations and the consolidation of democracy. American Journal of Political Science, 46:611-626.

Pevehouse, J. C. (2002b). Democracy from the outside-in? International organizations and democratization. International Organization, 56:515-549.

Przeworski, A. (1991). Democracy and the Market: Political and Economic Reforms in Eastern Europe and Latin America. Cambridge University Press, New York.

Przeworski, A. (2005). Democracy as an equilibrium. Public Choice, 123:253-273.

Przeworski, A., Alvarez, M., Cheibub, J. A., and Limongi, F. (2000). Democracy and Development: Political Regimes and Economic Well-being in the World, 1950-1990. Cambridge University Press, New York.

Przeworski, A. and Limongi, F. (1997). Modernization: Theories and facts. World Politics, 49:155-183.

Rosendorff, B. P. (2001). Choosing democracy. Economics 6 Politics, 13:1-29.

Ross, M. L. (2001). Does oil hinder democracy? World Politics, 53:325-361. 
Sala-i-Martin, X. (1997). I just ran two million regressions. American Economic Review, 87:178-183.

Schumpeter, J. (1942). Capitalism, Socialism, and Democracy. Harper, New York.

Seligson, M. A. (2002). The renaissance of political culture or the renaissance of the ecological fallacy? Comparative Politics, 34:273-292.

Simmons, B. A. and Elkins, Z. (2004). The globalization of liberalization: Policy diffusion in the international political economy. American Political Science Review, 98:171-189.

Sturm, J.-E. and de Haan, J. (2002). How robust is Sala-i-Martin's robustness analysis? University of Konstanz, mimeo.

Tomz, M., King, G., and Zeng, L. (1999). RELOGIT: Rare events logistic regression. http://gking.harvard.edu/stats.shtml\#relogit.

University of Texas Inequality Project (UTIP) (2007). UTIP-UNIDO dataset. Available at: http://utip.gov.utexas.edu/data/UTIP_UNIDO2001rv3.xls.

Vreeland, J. R. (2003). A continuous Schumpeterian conception of democracy. Yale University, mimeo.

Way, C. R. (2005). Political insecurity and the diffusion of financial market regulation. Annals of the American Academy of Political and Social Science, 598:125-144.

World Bank (2006). World Development Indicators. World Bank, Washington, D.C. 